\title{
Invited review: Enteric methane in dairy cattle production: Quantifying the opportunities and impact of reducing emissions
}

\author{
J. R. Knapp, ${ }^{\star 1}$ G. L. Laur,† P. A. Vadas, $¥$ W. P. Weiss, $\S$ and J. M. Tricarico\# \\ ${ }^{*}$ Fox Hollow Consulting LLC, Columbus, OH 43201 \\ †Gwinn-Sawyer Veterinary Clinic, Gwinn, MI 49841 \\ łUSDA Agricultural Research Service Forage Research Center, Madison, WI 53706 \\ $\S$ Department of Animal Sciences, The Ohio State University, Wooster 44691 \\ \#Innovation Center for US Dairy, Rosemont, IL 60018
}

\section{ABSTRACT}

Many opportunities exist to reduce enteric methane $\left(\mathrm{CH}_{4}\right)$ and other greenhouse gas (GHG) emissions per unit of product from ruminant livestock. Research over the past century in genetics, animal health, microbiology, nutrition, and physiology has led to improvements in dairy production where intensively managed farms have GHG emissions as low as $1 \mathrm{~kg}$ of $\mathrm{CO}_{2}$ equivalents $\left(\mathrm{CO}_{2} \mathrm{e}\right) / \mathrm{kg}$ of energy-corrected milk (ECM), compared with $>7 \mathrm{~kg}$ of $\mathrm{CO}_{2} \mathrm{e} / \mathrm{kg}$ of ECM in extensive systems. The objectives of this review are to evaluate options that have been demonstrated to mitigate enteric $\mathrm{CH}_{4}$ emissions per unit of ECM $\left(\mathrm{CH}_{4} / \mathrm{ECM}\right)$ from dairy cattle on a quantitative basis and in a sustained manner and to integrate approaches in genetics, feeding and nutrition, physiology, and health to emphasize why herd productivity, not individual animal productivity, is important to environmental sustainability. A nutrition model based on carbohydrate digestion was used to evaluate the effect of feeding and nutrition strategies on $\mathrm{CH}_{4} / \mathrm{ECM}$, and a meta-analysis was conducted to quantify the effects of lipid supplementation on $\mathrm{CH}_{4} / \mathrm{ECM}$. A second model combining herd structure dynamics and production level was used to estimate the effect of genetic and management strategies that increase milk yield and reduce culling on $\mathrm{CH}_{4} / \mathrm{ECM}$. Some of these approaches discussed require further research, but many could be implemented now. Past efforts in $\mathrm{CH}_{4}$ mitigation have largely focused on identifying and evaluating $\mathrm{CH}_{4}$ mitigation approaches based on nutrition, feeding, and modifications of rumen function. Nutrition and feeding approaches may be able to reduce $\mathrm{CH}_{4} / \mathrm{ECM}$ by 2.5 to $15 \%$, whereas rumen modifiers have had very little success in terms of sustained $\mathrm{CH}_{4}$ reductions without compromising milk production. More significant reductions of 15 to $30 \%$

Received July 6, 2013.

Accepted February 28, 2014.

${ }^{1}$ Corresponding author: joanne.r.knapp@gmail.com
$\mathrm{CH}_{4} / \mathrm{ECM}$ can be achieved by combinations of genetic and management approaches, including improvements in heat abatement, disease and fertility management, performance-enhancing technologies, and facility design to increase feed efficiency and life-time productivity of individual animals and herds. Many of the approaches discussed are only partially additive, and all approaches to reducing enteric $\mathrm{CH}_{4}$ emissions should consider the economic impacts on farm profitability and the relationships between enteric $\mathrm{CH}_{4}$ and other GHG.

Key words: enteric methane, methanogen, feed efficiency, lifetime productivity, mitigation

\section{INTRODUCTION}

\section{Methane and Greenhouse Gas Emissions}

Methane $\left(\mathrm{CH}_{4}\right)$, carbon dioxide $\left(\mathrm{CO}_{2}\right)$, nitrous oxide $\left(\mathrm{N}_{2} \mathrm{O}\right)$, and halocarbons are greenhouse gases (GHG) that enhance the effects of solar and thermal radiation on surface and atmospheric temperatures and are often expressed on a $\mathrm{CO}_{2}$-equivalent $\left(\mathbf{C O}_{2} \mathbf{e}\right)$ basis. Often, different and confusing bases are used in expressing the proportions of $\mathrm{GHG}$ and $\mathrm{CH}_{4}$ emissions from livestock agriculture (Lassey, 2008). Although enteric $\mathrm{CH}_{4}$ generated in the gastrointestinal tract of livestock is the single largest source of anthropogenic $\mathrm{CH}_{4}$ (Figure 1a), it is a lesser proportion of anthropogenic GHG emissions (Figure 1b). Methane has several natural sources (termites, wetlands, peat bogs, ocean sediments, and wildlife) and man-made sources (natural gas production, coal mining, wastewater treatment, landfills, and agriculture; Figure 1a; Lassey, 2008). Anthropogenic sources account for approximately $58 \%$ of total global $\mathrm{CH}_{4}$ emissions (Figure 1a; EPA, 2010, 2011a).

In "Livestock's Long Shadow," the Food and Agriculture Organization of the United Nations (Steinfeld et al., 2006) stated that global livestock agriculture was responsible for $18 \%$ of the anthropogenic GHG emissions annually. Since then, several groups have rebutted that report and provided reduced estimates of the impact of 
a)

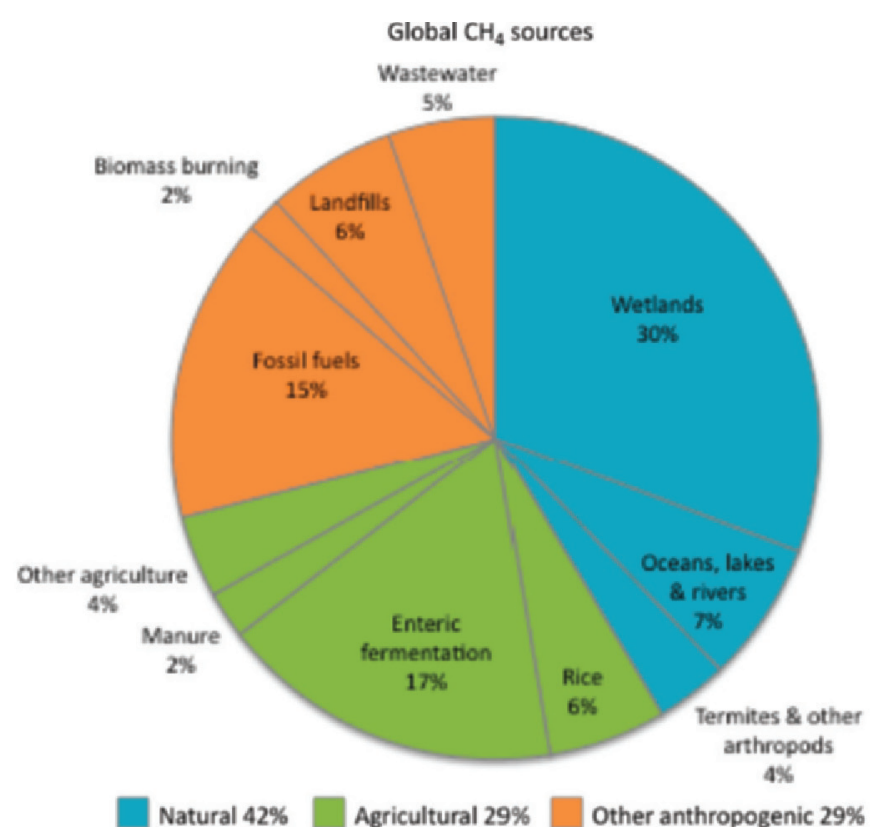

b)

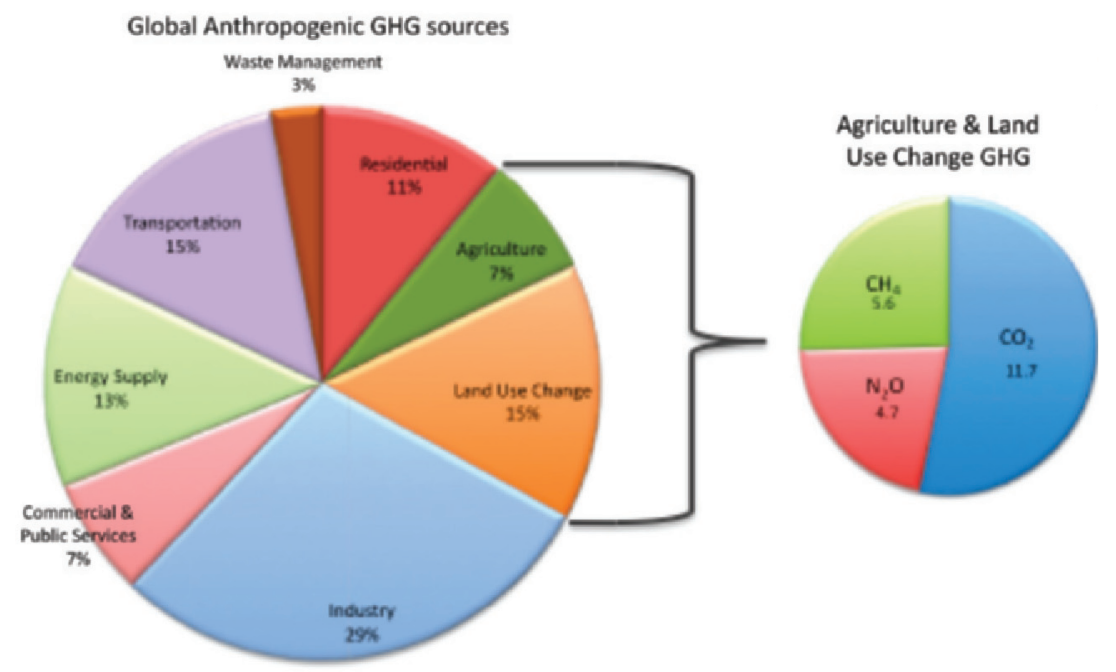

c)

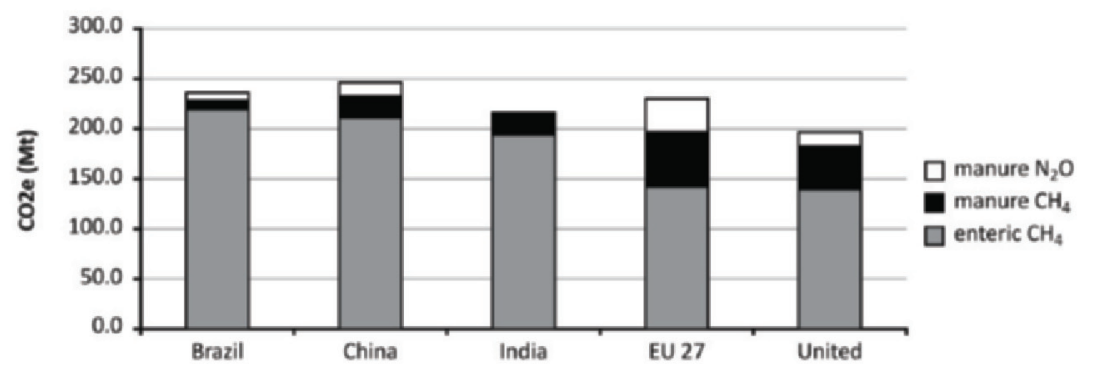

Figure 1. (a) Estimated proportion of global $\mathrm{CH}_{4}$ emissions from natural and anthropogenic sources. Sources comprising $1 \%$ or less are not shown and include wild animals, wildfires, permafrost, and anthropogenic stationary and mobile sources. More uncertainty exists in estimates of $\mathrm{CH}_{4}$ emissions from natural than from anthropogenic sources [data from EPA (2010) and EPA (2011a)]. (b) Global greenhouse gas (GHG) anthropogenic emissions by sector, with $\mathrm{CH}_{4}$ and $\mathrm{N}_{2} \mathrm{O}$ on a $\mathrm{CO}_{2}$-equivalent $\left(\mathrm{CO}_{2} \mathrm{e}\right)$ basis. Agriculture combined with land use change accounts for $22 \%$ of global greenhouse gas emissions. Deforestation accounts for $10.3 \%$ and fossil fuel utilization accounts for $1.4 \%$ of $\mathrm{CO}_{2}$ released; biogenic $\mathrm{CO}_{2}$ is not included [data from analysis by Ecofys (2013)]. (c) The 5 countries and regions with the largest livestock-associated enteric $\mathrm{CH}_{4}$ emissions on a million-metric-tonne (Mt)-of- $\mathrm{CO}_{2}$ e basis. In the United States, $95 \%$ of enteric $\mathrm{CH}_{4}$ arises from ruminant livestock (EPA, 2011b); this

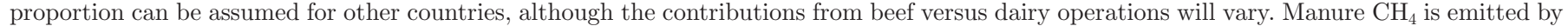
storage systems where anaerobic fermentation occurs. Manure $\mathrm{CH}_{4}$ and $\mathrm{N}_{2} \mathrm{O}$ can be from either ruminant or nonruminant livestock operations [data source: EPA (2011a)]. EU $27=$ European Union countries. 
livestock agriculture on GHG emissions (Pitesky et al., 2009; EPA, 2011a; Petherick, 2012). Land use change (for example, converting forest or permanent pasture to annual crops) contributes a significant portion and, when combined with existing agriculture, accounts for 14 to $22 \%$ of global anthropogenic GHG emissions (Figure 1b; Shafer et al., 2011; Ecofys, 2013), although some analyses attribute little land use change to dairy production (Gerber et al., 2013; Golub et al., 2013). Approximately $37 \%$ of global agricultural $\mathrm{CH}_{4}$ and $\mathrm{N}_{2} \mathrm{O}$ arise from direct animal and manure emissions, and the remainder is associated with cropping and deforestation (EPA, 2011a). On a world-wide basis, dairy animals, including cull cows and beef cattle from dairy breeds, are estimated to contribute only $4 \%$ to anthropogenic GHG emissions (FAO, 2010). In many developed countries, the contribution of dairy production to GHG emissions is estimated even lower, due to the higher productivity of livestock agriculture, the dilution by emissions from other sectors, and lack of significant land use change (Hagemann et al., 2011). In the European Union 15, beef and dairy cattle are estimated to contribute 2.1 and $1.2 \%$, respectively (EEA, 2011), to anthropogenic GHG inventories, and in the United States, all livestock (including nonruminants) and dairy cattle are estimated to contribute 2.75 and $0.55 \%$, respectively, to anthropogenic GHG emissions (EPA, 2011b). However, in developed countries where pastoral agriculture is a significant portion of the economy (e.g., Ireland and New Zealand) or developing countries with large cattle populations (e.g., Brazil and India), ruminant livestock can be a very large contributor to the national GHG inventory (FAO, 2010).

Examining $\mathrm{CH}_{4}$ emissions from livestock agriculture as a proportion of total anthropogenic GHG emissions in a given country or region can be misleading. Methane emissions are a function of the population of ruminant animals, their level of production, and the associated manure-handling systems. Thus, the countries or regions with the largest cattle populations in the world contribute the most to global agricultural $\mathrm{CH}_{4}$ emissions on a million-metric-tonne basis (metric tonnes of $\mathrm{CO}_{2} \mathrm{e}$; Figure 1c). Why should the dairy industry in any country be concerned about $\mathrm{CH}_{4}$ emissions? First, international policy discussions have focused on non- $\mathrm{CO}_{2}$ emissions such as $\mathrm{CH}_{4}$ and $\mathrm{N}_{2} \mathrm{O}$ because they are less expensive to mitigate than $\mathrm{CO}_{2}$ emissions (EPA, 2006; FAO, 2010; Shafer et al., 2011; Gerber et al., 2013). Often, $\mathrm{CH}_{4}$ mitigation approaches can be economically advantageous as well as environmentally beneficial. Second, because the $\mathrm{CO}_{2}$ emitted by livestock, including dairy cattle, arises from metabolism of plant-derived feedstuffs, it is viewed as part of a continuous biological cycle of fixation, uti- lization, and exhalation. Accordingly, it is defined as biogenic $\mathrm{CO}_{2}$ and livestock are considered to be a zero net source of $\mathrm{CO}_{2}$ (Pitesky et al., 2009). Third, enteric and manure $\mathrm{CH}_{4}$ comprise more than $40 \%$ of the GHG emissions associated with fluid milk production in the United States (Thoma et al., 2013). Last, some retailers and consumers in both domestic and international markets are concerned about the contribution of GHG emissions to the carbon footprint of foods. Ruminant livestock will play a crucial role in future global food security because far more grazing land exists, unusable for human food, than cropping land (Gill et al., 2010) and ruminant animals can transform pasture into highquality human food. Ruminants also are very capable of converting the human-inedible by-products of food production into high-quality human food. If mitigation strategies are implemented that reduce GHG but also reduce production output, then the environmental benefits would be at least partly negated by increased food costs or reduced supply of animal-based foods.

Enteric $\mathrm{CH}_{4}$ comprises 17 and $3.3 \%$ of global $\mathrm{CH}_{4}$ and GHG emissions, respectively, and is largely derived from ruminant livestock (Figures $1 \mathrm{a}$ and $1 \mathrm{~b}$ ). Manure $\mathrm{CH}_{4}$ from both ruminant and nonruminant livestock contributes 2 and $0.4 \%$ of global $\mathrm{CH}_{4}$ and GHG emissions, respectively (Figures 1a and 1b). Several country and regional GHG inventories do not differentiate between ruminant and nonruminant livestock production systems with regard to manure GHG emissions. Manure $\mathrm{CH}_{4}$ emissions are a larger proportion of total farm $\mathrm{CH}_{4}$ emissions in intensively managed dairy operations with manure storage systems, and much lower in extensive or grazing operations (Figure 1c). Manure $\mathrm{N}_{2} \mathrm{O}$ emissions contribute $<1 \%$ of global GHG emissions (Ecofys, 2013). Significant interrelationships exist between enteric $\mathrm{CH}_{4}$ and manure $\mathrm{CH}_{4}$ and $\mathrm{N}_{2} \mathrm{O}$ emissions, and accordingly, mitigation approaches targeted at reducing enteric $\mathrm{CH}_{4}$ must consider the effect on manure $\mathrm{CH}_{4}$ and $\mathrm{N}_{2} \mathrm{O}$ emissions. Because of the larger contribution of enteric $\mathrm{CH}_{4}$ than manure $\mathrm{CH}_{4}$ and $\mathrm{N}_{2} \mathrm{O}$ in dairy production to agricultural GHG emissions, this review focuses on enteric $\mathrm{CH}_{4}$. Readers are referred to Gerber et al. (2013) and Hristov et al. (2013) for an integrated discussion of enteric and manure GHG emissions and mitigation opportunities from ruminant livestock.

This review will provide a broad, integrated view of $\mathrm{CH}_{4}$ mitigation opportunities in dairy production for agricultural students and scientists. The objectives are to (1) evaluate options that have been demonstrated to mitigate enteric $\mathrm{CH}_{4}$ emissions from dairy cattle on a quantitative basis and in a sustained manner; (2) integrate approaches in genetics, feeding and nutrition, physiology, and health to emphasize why herd productivity, not individual animal productivity, is 
important to environmental sustainability; and (3) provide perspective on the relative contribution of enteric $\mathrm{CH}_{4}$ emissions from dairy production to global GHG emissions. The majority of the research presented was conducted under intensive management conditions in temperate climates. In principle, the approaches discussed can be applied to any dairy production system because their aim is increasing productivity at the herd level. Enteric $\mathrm{CH}_{4}$ per unit of ECM ( $\mathrm{g}$ of $\mathrm{CH}_{4}$ / $\mathrm{kg}$ of $\mathrm{ECM}$ ) will be the evaluation basis for 2 reasons. First, dairy farmers will not be willing to implement $\mathrm{CH}_{4}$ mitigation strategies if they decrease milk production, for which farmers are not compensated. Second, as the world population continues to grow during this century, agriculture must focus on production efficiency to provide an adequate food supply, and milk and dairy foods are an important source of calories as well as protein and micronutrients. Thus, enteric $\mathrm{CH}_{4}$ emissions per unit of ECM $\left(\mathrm{CH}_{4} / \mathrm{ECM}\right)$ is the correct and most useful basis biologically, nutritionally, environmentally, and economically. Some of the mitigation approaches can be readily implemented at this time, and others need short-term development (2 to $5 \mathrm{yr}$ ). In vitro studies are presented where appropriate, but the focus of this article is in vivo research. Although in vitro studies are a valuable way to test ideas, in vivo experiments are imperative for obtaining quantitative results that capture the complexity and dynamics of ruminant digestion and metabolism and the consequences on lactation performance.

To identify effective mitigation strategies, accurate and repeatable measurement techniques are required. Several direct and indirect methods have been used to quantify $\mathrm{CH}_{4}$ emissions in vivo, many of which were reviewed by Johnson and Johnson (1995), Kebreab et al. (2006), and Storm et al. (2012), including their advantages, disadvantages, and limitations. The most common in vivo measurement techniques are respiration calorimetry (either closed or open-circuit), polyethylene tunnel system, isotope dilution, tracer gas [i.e., sulfur hexafluoride $\left.\left(\mathrm{SF}_{6}\right)\right]$, and micrometeorological mass balance (Kebreab et al., 2006). New technologies are also being developed to assess $\mathrm{CH}_{4}$ concentrations on an hourly basis using rumen sensors (Laporte-Uribe and Gibbs, 2009) or in commercial operations by measuring $\mathrm{CH}_{4}$ eructated during eating in robotic milking stations or at pasture feeders (Utsumi et al., 2011). Comparisons of the measurement techniques have identified systematic differences (Kebreab et al., 2006; Muñoz et al., 2012). Respiration chambers remain the gold standard in research settings that permit animal confinement. Improvement of the other existing methodologies or development of new methodologies that allow for repeatable, accurate $\mathrm{CH}_{4}$ emission measurements from groups of animals or in different housing situations is critical in evaluating mitigation strategies.

\section{Rumen Function: Ecology and Biochemistry}

Ruminant animals and microbes have evolved together, filling a niche based on the conversion of complex plant carbohydrates to energy that is beneficial to both the host animal and the microbial symbionts. The microbes include bacteria, protozoa, fungi, and Archaea (Figure 2). The rumen ecosystem is an anaerobic environment, in which the degradation of plant material occurs in a very short time frame compared with other anaerobic ecosystems such as wetlands and estuaries, and the fermentation products are different. Some of the microbial species have coevolved with ruminants and hindgut-fermenting mammals and do not exist in any other environment (e.g., rumen protozoa). Also, the methanogens of ruminants and other mammalian herbivores are distinct from methanogens in other environments. To date, 3 major genera and 3 minor genera of methanogens belonging to the Archaea domain have been identified, although it is likely that more exist (Wright et al., 2006; Janssen and Kirs, 2008; Liu and Whitman, 2008; Kong et al., 2013; Poulsen et al., 2013). Only 8 methanogen species have been cultured (Kong et al., 2013) and the total number of rumen archaeal species is unknown (Janssen and Kirs, 2008), but has been estimated to be approximately 360 to 1,000 on an operational taxonomic unit basis (Kim et al., 2011; Kong et al., 2013). Methanogens are found in the hindgut as well as the rumen, although the population structure, ecology, and microbial metabolism differ between the 2 compartments.

In the reticulorumen and hindgut, simple and complex carbohydrates are hydrolyzed to 5- and 6-carbon sugars by microbial enzyme activity. Sugars are fermented to VFA through multiple-step pathways that produce reducing equivalents (i.e., metabolic hydrogen), which can be summarized in the following equations (Hungate, 1966; Czerkawski, 1986; Moss et al., 2000):

$$
\begin{gathered}
\text { Glucose } \rightarrow 2 \text { pyruvate }+4 \mathrm{H} \\
(\text { carbohydrate metabolism }) ; \\
\text { Pyruvate }+\mathrm{H}_{2} \mathrm{O} \rightarrow \text { acetate }+\mathrm{CO}_{2}+2 \mathrm{H} ; \\
\text { Pyruvate }+4 \mathrm{H} \rightarrow \text { propionate }+\mathrm{H}_{2} \mathrm{O} ; \\
2 \text { acetate }+4 \mathrm{H} \rightarrow \text { butyrate }+2 \mathrm{H}_{2} \mathrm{O} .
\end{gathered}
$$

The metabolic hydrogen is converted to $\mathrm{H}_{2}$ by hydrogenase-expressing bacterial species, and the $\mathrm{H}_{2}$ converted to $\mathrm{CH}_{4}$ by Archaea in the combined reaction: 


$$
\mathrm{CO}_{2}+8 \mathrm{H} \rightarrow \mathrm{CH}_{4}+2 \mathrm{H}_{2} \mathrm{O} \text { (methanogenesis). }
$$

Dissolved $\mathrm{H}_{2}$ inhibits ruminal fermentation pathways through negative feedback mechanisms, and if not removed by the methanogens, will reduce the overall extent of carbohydrate degradation, the rate of microbial growth, and the synthesis of microbial protein (Wolin, 1974; McAllister and Newbold, 2008). Biohydrogenation of FA provides an alternative hydrogen sink to methanogenesis (Figure 2). Degradation of dietary protein and assimilation into microbial protein can result in either a net consumption or net production of hydrogen (Figure 2; Hungate, 1966; Czerkawski, 1986). Additionally, previously unknown methanogens of the order Thermoplasmatales that use methyl groups rather than $\mathrm{H}_{2}$ have been recently identified in the rumen (Poulsen et al., 2013). This group and other unidentified organisms may help explain the lack of predictability in the effects of various rumen manipulations that has been observed in the past.

As a consequence of the complex $\mathrm{H}_{2}$ and methyl group metabolism in the reticulorumen, changes in pathways leading to VFA production, biohydrogenation, microbial $\mathrm{N}$ metabolism, and microbial growth will alter the amount of $\mathrm{CH}_{4}$ produced (Figure 2). These changes are dynamic functions of both microbial populations (species, abundance, and activity of microbes) and which pathways are being utilized, which contributes to the complexity and difficulty of predicting $\mathrm{CH}_{4}$ emissions and developing mitigation strategies.

\section{METHANE MITIGATION STRATEGIES}

An abundance of $\mathrm{CH}_{4}$ mitigation strategies have been studied and they can be classified into 3 broad categories:

1. Feeds, feeding management, and nutrition: feeding good-quality feeds can increase animal productivity and feed efficiency. Certain feeds can enhance propionate or decrease acetate production (Equations 2 and 3), decreasing $\mathrm{H}_{2}$ that would be converted to $\mathrm{CH}_{4}$.

2. Rumen modifiers: feeding specific substances that directly or indirectly inhibit methanogenesis or using biological control (defaunation, bacteriocins, bacteriophages, and immunization) directed at reducing methanogens.

3. Increasing animal production through genetics and other management approaches: improving nutrient utilization for productive purposes to dilute out maintenance on an individual animal or a herd basis, increasing feed efficiency and decreasing $\mathrm{CH}_{4}$ per unit of product (meat or milk).

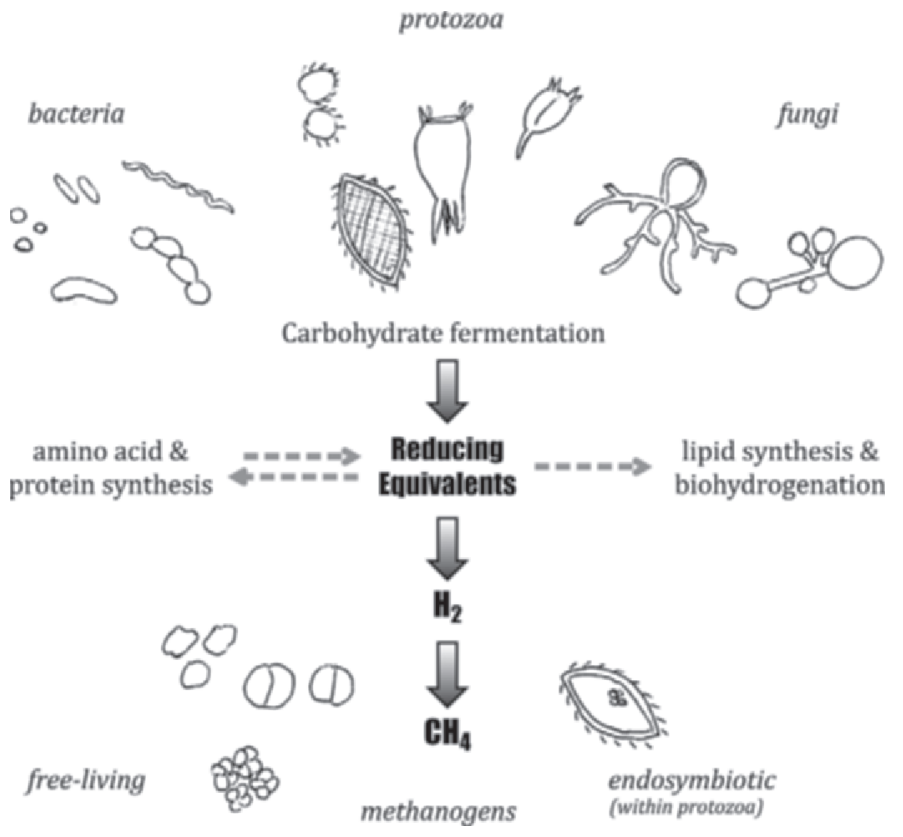

Figure 2. Rumen microorganisms, including bacteria, protozoa, and fungi, ferment carbohydrates to obtain energy and generate significant amounts of reducing equivalents $\left(\mathrm{FADH}_{2}, \mathrm{NADH}\right.$, and others) in the process and VFA (not shown) and $\mathrm{H}_{2}$ as end products. Methanogens, both free living and endosymbionts inside protozoa, convert $\mathrm{H}_{2}$ to $\mathrm{CH}_{4}$. A small amount of reducing equivalents are utilized in lipid synthesis and FA biohydrogenation. Synthesis of amino acids can result in production or utilization of reducing equivalents, but the net amount is small. Protein synthesis utilizes reducing equivalents. Elevated concentrations of $\mathrm{H}_{2}$ inhibit carbohydrate fermentation, providing a negative feedback mechanism. Organisms are not drawn to scale [after Czerkawski (1986)].

Total $\mathrm{CH}_{4}$ emissions will be decreased if annual production of milk remains constant and fewer cows are needed to produce the same amount of milk.

Although dairy cows are of primary concern, studies using other ruminant animals (sheep, goats, or beef cattle) are included as appropriate for reference. Many of the principles behind $\mathrm{CH}_{4}$ reduction can be generalized to include all ruminants. However, the right mitigation approach must be adapted to the specific needs of the farmers and animals. Although the majority of the $\mathrm{CH}_{4}$ mitigation approaches discussed were studied with animals in confinement housing and fed feeds grown in temperate climates, with appropriate consideration of the underlying biology, their application can be extended to other production systems. Most importantly, mitigation strategies should be cost effective or cost neutral if we expect farmers to adopt the changes.

\section{Feeds, Feeding Management, and Nutrition}

Nutritional mitigation of $\mathrm{CH}_{4}$ production is founded on 3 basic approaches: (1) ingredient selection to alter 
VFA production patterns; (2) increased rate of passage, which can alter microbial populations and VFA production patterns and shift some digestion to the intestines; and (3) feeding better-quality diets to increase milk production per cow, which will dilute the $\mathrm{CH}_{4}$ cost associated with maintenance energy requirements.

Feed ingredients provide the substrates for microbial fermentation, and differences in feed digestibility and chemical composition alter the amount of energy extracted by the microbes and the patterns of VFA and $\mathrm{CH}_{4}$ produced. The proportions of VFA affect the amount of $\mathrm{CH}_{4}$ produced, because propionate formation consumes reducing equivalents, whereas acetate and butyrate formation generate $\mathrm{H}_{2}$ for methanogenesis (Hungate, 1966). As such, any dietary component or intervention that causes a shift in favor of propionate production will be accompanied by a reduction in $\mathrm{CH}_{4}$ production per unit of feed fermented, whereas the opposite is true for acetate and butyrate (Van Nevel and Demeyer, 1996). Rumen protein degradation and assimilation into microbial protein can result in either a net consumption or net production of $\mathrm{H}_{2}$ (Figure 2; Hungate, 1966; Czerkawski, 1986). Biohydrogenation of FA will result in a net consumption of $\mathrm{H}_{2}$ (Figure 2). Consequently, variations in rumen $\mathrm{N}$ metabolism and biohydrogenation will cause alterations in $\mathrm{CH}_{4}$ production, and because carbohydrate and protein substrates are also used for microbial maintenance and growth, theoretical predictions of VFA patterns and $\mathrm{CH}_{4}$ formation do not always correlate to in vitro and in vivo observations (Hironaka et al., 1996).

Passage rate also affects the extent of digestion and patterns of VFA formation as well as microbial growth rates and has been found to explain $28 \%$ of the variation in $\mathrm{CH}_{4}$ emissions (Okine et al., 1989). Faster passage of feed material out of the rumen means a lower extent of rumen fermentation and possibly less $\mathrm{CH}_{4}$ production per unit of feed, depending on whether the feed nutrients are digested in the small intestine (sugars and starches) or fermented in the hindgut (pectin, glucans, and NDF). Increased passage rates also increase microbial energy requirements because cells have to divide more frequently to maintain rumen populations.

High-quality (more energy-dense or more digestible) diets provide more energy for production as a proportion of the gross energy intake (GEI) and dilute the costs of maintenance than low-quality diets; therefore less $\mathrm{CH}_{4} / \mathrm{ECM}$ is generated (Figure 3). More energydense diets usually contain higher proportions of starch relative to NDF, and less $\mathrm{CH}_{4}$ is produced per unit of starch digested than NDF (Moe and Tyrrell, 1979). These diets also can increase net energy intake and if the net energy is partitioned to milk, it will decrease $\mathrm{CH}_{4} / \mathrm{ECM}$ production. However, reducing enteric $\mathrm{CH}_{4}$ has a small effect on animal energetics. For a cow producing $30 \mathrm{~kg}$ of ECM and $450 \mathrm{~g}$ of $\mathrm{CH}_{4}$ per day, a $15 \%$ reduction in $\mathrm{CH}_{4} / \mathrm{ECM}$ would provide an additional 0.9 $\mathrm{Mcal} / \mathrm{d}$ to an estimated ME intake of 53 to $57 \mathrm{Mcal} / \mathrm{d}$, assuming that digestibility is not affected.

These alterations in digestibility, proportions of VFA produced, and microbial growth affect energy and protein availability to the cow and, ultimately, the efficiency at which the feed nutrients are used for productive functions, including growth and milk synthesis (NRC, 2001). Based on these 3 principles, $\mathrm{CH}_{4}$ emissions can be affected by the level of feed intake, type of carbohydrate, forage quality and species, physical processing, forage preservation, and feeding frequency (Table 1).

Level of Intake, Digestibility, and Passage. Many studies have found that variation in DMI accounts for 52 to $64 \%$ of the variation in $\mathrm{CH}_{4}$ production on a per day basis when cattle were fed ad libitum (Boadi and Wittenberg, 2002; Pinares-Patiño et al., 2007; Hammond et al., 2009). To account for the effects of DMI on digestibility, a static model was developed based on reductions in starch digestibility (Firkins et al., 2001) and NDF digestibility (Huhtanen et al., 2009) with increasing DMI and using $\mathrm{CH}_{4}$ prediction equations based on digestible carbohydrate fractions (Moe and Tyrrell, 1979). Dry matter intake was predicted from milk yield and composition using the dairy NRC (2001) model, and results for a 680-kg lactating cow consuming a ration with $50 \%$ forage, $30 \% \mathrm{NDF}$, and $25 \%$ starch are shown in Figure 3 . Total $\mathrm{CH}_{4}$ production (g or Mcal/d) increases with increasing DMI because there is more feed to be fermented (Figure 3a). However, $\mathrm{CH}_{4}$ as a proportion of DMI or GEI ( $\mathrm{g}$ of $\mathrm{CH}_{4}$ ) $\mathrm{kg}$ of GEI) usually decreases as DMI increases above maintenance (Blaxter and Clapperton, 1965; Moe and Tyrrell, 1979; Pinares-Patiño et al., 2009) and is related to decreases in DM digestibilities observed at higher intakes and the associated increases in passage rates (Figure 3b). The relationship between $\mathrm{CH}_{4}$ emitted $(\mathrm{kg} / \mathrm{d}$ or Mcal $/ \mathrm{d}$ ) and DMI or GEI is not constant, but decreases as intake increases. Accordingly, $\mathrm{CH}_{4} / \mathrm{ECM}$ decreases with increasing DMI and milk yield (Figure $3 a)$. For example, a cow producing $30 \mathrm{~kg}$ of milk/d and consuming a $50 \%$ forage and $50 \%$ concentrate ration is predicted to emit $12.7 \mathrm{~g}$ of $\mathrm{CH}_{4} / \mathrm{kg}$ of ECM compared with a cow producing $35 \mathrm{~kg}$ of milk/d with the same diet, emitting $11.9 \mathrm{~g}$ of $\mathrm{CH}_{4} / \mathrm{kg}$ of ECM.

Whereas digestibility was estimated to decrease $4.6 \%$ per multiple of maintenance in the older literature (Tyrell and Moe, 1975), under current feeding situations with better-quality forages and improved feeding management, digestibility depression is probably $<2$ or 3\% per multiple of maintenance (Vandehaar, 1998; Sauvant and Giger-Reverdin, 2009). Also, it is possible 
a)

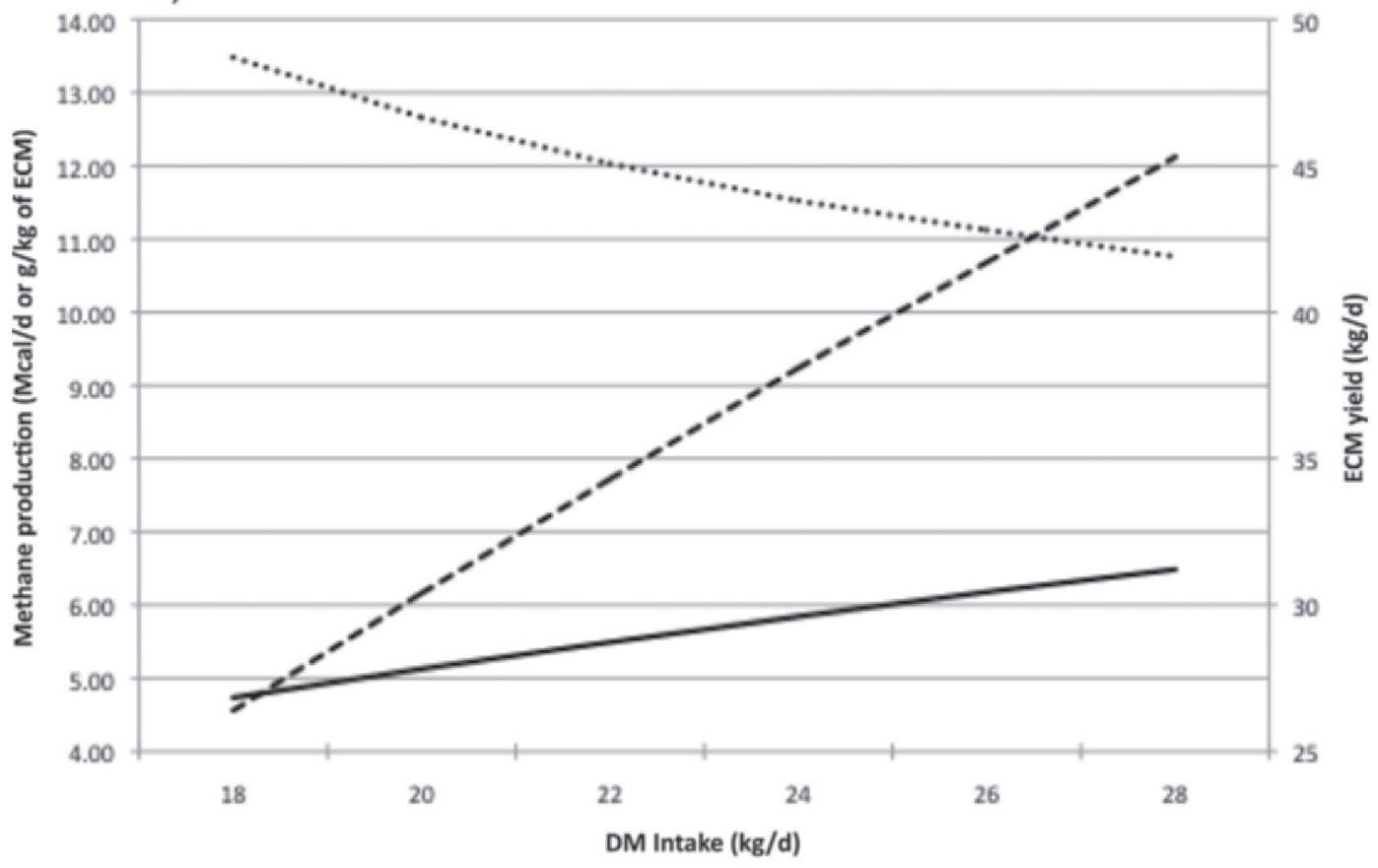

b)

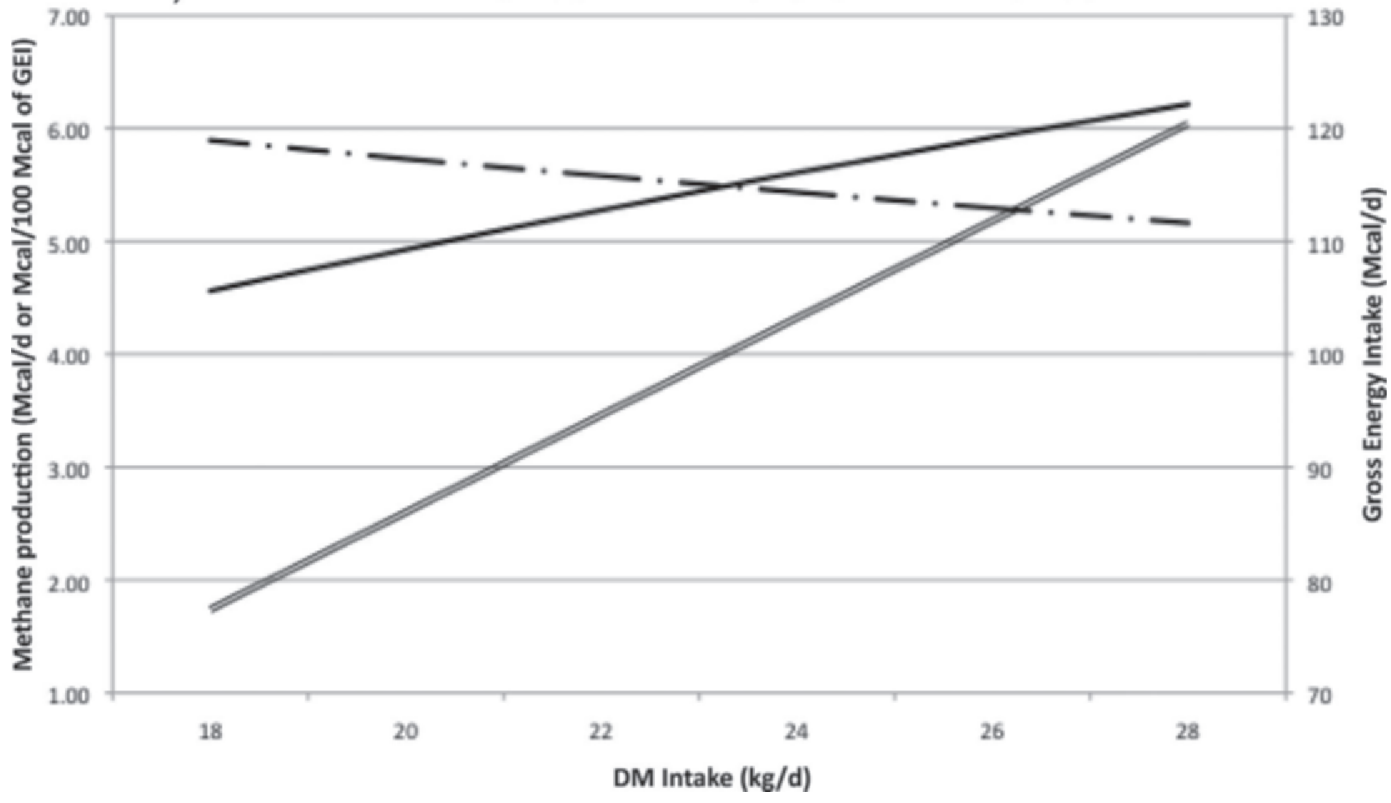

Figure 3. (a) Energy-corrected milk yield (dashed line) increases more rapidly than $\mathrm{CH}_{4}$ production (solid line) with increasing DMI, resulting in less enteric $\mathrm{CH}_{4}$ emissions per unit of ECM $\left(\mathrm{CH}_{4} / \mathrm{ECM}\right.$; dotted line). (b) Corresponding decreases in $\mathrm{CH}_{4}$ as a proportion of gross energy intake [GEI; $\mathrm{g}$ of $\mathrm{CH}_{4} / \mathrm{kg}$ of GEI (Ym; $\mathrm{CH}_{4} / \mathrm{GEI}$ ); dashed + dotted line] are predicted. Predictions are based on a model that accounts for the effects of DMI on starch and NDF digestibility, as described in the text. Note that although the methane production functions $\mathrm{CH}_{4} / \mathrm{ECM}$ and $\mathrm{CH}_{4} / \mathrm{GEI}$ appear linear over the range shown, they are in fact curvilinear, decreasing with increasing intakes.

that genetic selection for higher milk yields in dairy cattle has been accompanied by increased digestive capacity. No definitive research is available on whether the increased capacity is due to increases in rumen or total gastrointestinal tract volume, absorptive surface, changes in host-microbe interactions, or combinations of these effects. In dairy cattle diets, most of the decrease in DM digestibility observed as intake increases 
Table 1. Summary of feeding management approaches to altering rumen fermentation and reducing $\mathrm{CH}_{4}$ emissions per unit of ECM ${ }^{1}$

\begin{tabular}{ll}
\hline Feeding alteration & $\mathrm{CH}_{4} / \mathrm{ECM}$ \\
\hline Increased DMI & Decreased 2 to $6 \%$ for each kilogram increase
\end{tabular}

Assumption(s) and comments

\section{Decreased forage particle size}

Grain processing

Rumen $\mathrm{pH}<5.5$

Increased concentrate feeding

Increased forage quality achieved by better management of harvesting and storage or pasture management

Forage type/strain selection and genetics

(e.g., brown midrib corn)

Lipid feeding

\section{Neutral}

Decreased 1 to $2.5 \%$ with $5 \%$ increase in apparent total-tract starch digestibility

Decreased 15 to $20 \%$

Decreased $2 \%$ for every $1 \%$ increase in ration NFC; maximum reduction $\sim 15 \%$

Decreased up to $5 \%$ with a 5 percentage unit increase in apparent total-tract NDF digestibility

Decreased 0 to $4 \%$

Decreased $5 \%$ per unit of ether extract in ration

(a) Increased fill; (b) increased rate of solids passage; (c) decreased rumen NDF digestibility will be compensated by increased hindgut NDF digestibility; (d) decreased rumen starch digestibility; (e) increased starch digestion in small intestine; (f) no difference in total-tract starch digestion; (g) increased production (a) Increased passage of forage particles from the rumen; (b) decreased rumen NDF digestibility will be compensated by increased hindgut NDF digestibility (a) Decreased grain particle passage from rumen; (b) increased VFA yield with increased proportion of propionate; (c) no increase in intake of digestible DM (which may or may not be true)

(a) Decreased rumen NDF digestibility not fully compensated for by hindgut fermentation; (b) assumes $50 \%$ reduction in apparent total-tract NDF digestibility; (c) milk yield reduced 10 to $15 \%$; (d) no change in rumen starch digestibility and no effect on DMI

(a) Effects manifested by less NDF fermented in total tract, shift of starch digestion from rumen to small intestine, and possibly lower rumen $\mathrm{pH} ;(\mathrm{b})$ potential to increase intake; (c) higher proportions of propionate (a) Increased yield of VFA (energy) is greater than increases in $\mathrm{CH}_{4}$; (b) increased milk yield

Improvements in digestibility lead to increased DMI, energy availability, and milk yields

Potential for (a) decreased DMI, (b) decreased NDF digestibility, (c) decreased lactation performance, and (d) decreased milk components

${ }^{1}$ Many of the biological effects are interrelated and interdependent and, accordingly, the changes in enteric $\mathrm{CH}_{4}$ emissions per unit of ECM $\left(\mathrm{CH}_{4} / \mathrm{ECM}\right)$ are not likely to be additive. Expected decreases in $\mathrm{CH}_{4} / \mathrm{ECM}$ range from 0 to $15 \%$. These changes are modest because the range of alterations was restricted to what might reasonably be implemented or occur in commercial dairy production without compromising milk yield significantly (except as noted for rumen $\mathrm{pH}$ ) compared with previously published reviews where the manipulations ranged from all-forage to all-concentrate diets for nonlactating and lactating animals. Manipulations that alter carbohydrate digestibility and thus energy availability will affect milk yield as well as $\mathrm{CH}_{4}$ emissions 
is associated with a decrease in total-tract NDF digestibility, but not total-tract starch digestibility (Huhtanen et al., 2009), although starch digestion will be shifted from the rumen to the small intestine (Firkins et al., 2001). Huhtanen et al. (2009) predicted that for every kilogram increase in DMI, total-tract NDF digestibility is reduced $0.485 \pm 0.143 \%$ for grass silages. Whether a similar reduction may be observed with NDF digestibility in legume or corn silages with increasing DMI is not known, but is presumed to be different. Assuming unchanged patterns of fermentation, the reduction in total-tract NDF digestibility with increasing DMI of the same diet will result in a proportional reduction in $\mathrm{CH}_{4}$ emissions on a per-head-per-day basis.

Methane emission would also be expected to be affected by depression of ruminal starch digestibility with increasing intakes. Apparent ruminal starch digestibility was found to decrease linearly with increasing DMI by $1.21 \pm 0.59 \% / \mathrm{kg}$ of DMI (Firkins et al., 2001). When ruminal starch digestibility is decreased, the majority of the starch passing out of the rumen will be digested in the small intestine rather than being fermented in the hindgut (Firkins et al., 2001; Huntington et al., 2006). In theory, intestinal digestion of starch should be more energetically favorable to the animal than ruminal fermentation to VFA, but in practice, no difference in energy availability has been demonstrated between the two (Huntington et al., 2006). With lower ruminal digestibility of NDF, more NDF will pass out of the rumen and be passed to the hindgut, where it can be fermented and produce $\mathrm{CH}_{4}$. Although the decrease in total-tract NDF digestibility with increasing DMI is less than the decrease in ruminal starch digestibility, in terms of $\mathrm{CH}_{4}$ production, the impact on NDF digestibility is expected to be larger because fermentation of hemicellulose and cellulose results in 2 to 5 times more $\mathrm{CH}_{4}$ than fermentation of NFC (Moe and Tyrrell, 1979). The quantitative extent of the decrease in $\mathrm{CH}_{4}$ emission with increasing DMI will depend on the proportions of starch and NDF in the diet and the proportions of cellulose and hemicellulose in the forages (legumes vs. grasses; further discussion in the next section).

Typically, the rate of passage increases with increasing DMI, decreasing the extent of ruminal degradation of the OM (Boadi et al., 2004). Associated $\mathrm{CH}_{4}$ losses decrease by 0.77 to $1.6 \%$ GEI for each multiple or unit increase of intake (Johnson and Johnson, 1995; Beauchemin and McGinn, 2006a; Sauvant and Giger-Reverdin, 2009). The dairy NRC model (NRC, 2001) models the decrease in digestibility with increasing intake using the same discount factor for all feed nutrients (NDF, NFC, and CP). To account for the observation that the digestibility of all feed components are not equally depressed with increasing DMI, models are needed that allow for variable digestibility discount factors by individual nutrients. Also, interactions between intake level and diet composition exist in $\mathrm{CH}_{4}$ as a proportion of gross energy (Sauvant and Giger-Reverdin, 2009). The relationships between digestibility, passage, and DMI are complex and have a major impact on rumen production of $\mathrm{CH}_{4}$. Both the rate and the extent of rumen carbohydrate digestion determine the amount of $\mathrm{CH}_{4}$ produced and the energy available for milk synthesis.

Type of Carbohydrates. Greater DMI with greater milk yields and lesser $\mathrm{CH}_{4}$ yields are often achieved by feeding more digestible carbohydrates. The relative proportion of fermentation end products in the rumen, especially the VFA, is influenced by the proportion of NDF versus NFC in the ration (Moe and Tyrrell, 1979; Murphy et al., 1982; Sutton et al., 2003; Bannink et al., 2006). Forage-based diets high in cellulose, hemicellulose, and lignin favor production of acetate and butyrate (Moe and Tyrrell, 1979), whereas starch-based diets favor propionate production (Johnson and Johnson, 1995). Soluble sugars tend to stimulate greater proportions of butyrate and also increase fiber digestibility (Hindrichsen et al., 2005). However, selecting ryegrass forage for increased soluble carbohydrates did not reduce $\mathrm{CH}_{4} / \mathrm{ECM}$ due to reduced NDF digestibility that negatively affected milk yield (Staerfl et al., 2012). In contrast, increasing NFC by altering the nonforage portion of the ration from 32 to $53 \%$ with corn grain, soybean meal, and whole roasted soybeans decreased $\mathrm{CH}_{4} / \mathrm{ECM}$ by $20 \%$ in early-lactation cows (Aguerre et al., 2011).

Neutral detergent fiber is heterogeneous with respect to chemical composition, digestibility, and potential to produce $\mathrm{CH}_{4}$. The highly digestible NDF in brewers and distillers by-products produces half to one-third of the $\mathrm{CH}_{4}$ per kilogram of DM digested in vitro compared with forages with similar DM digestibilities (Johnson and Johnson, 1995). Given that distillers and brewers grains have high hemicellulose:cellulose ratios (1.5 to $1.6: 1)$ compared with grasses $(0.67: 1)$ and legumes (0.35:1), this observation fits well with the Moe and Tyrrell (1979) equation, where digested hemicellulose produces only $37 \% \mathrm{CH}_{4}$ relative to digested cellulose. Cows fed increasing amounts of dried distillers grains with solubles that replaced corn and soybean meal emitted less $\mathrm{CH}_{4}$ (g/d) and $\mathrm{CH}_{4} / \mathrm{ECM}$ (Benchaar et al., 2013). In that study, changes in carbohydrate sources were confounded by treatment changes in diet lipid content sulfur intakes, and DMI. Tropical grasses (C4) tend to be less digestible than temperate (C3) forages due to their higher NDF content and greater lignification, and produce more $\mathrm{CH}_{4}$ per unit of intake (PinaresPatiño et al., 2009; Archimède et al., 2011). In contrast, tropical legumes are significantly less digestible and 
produce less $\mathrm{CH}_{4}$ per unit of intake than temperate legumes (Archimède et al., 2011). The greater content of tannins and other secondary metabolites in tropical legumes affects NDF digestibility and $\mathrm{CH}_{4}$ production (Archimède et al., 2011); however, the authors did not use NDF digestibility in their analysis.

High-starch, cereal grain-based diets stimulate the growth and metabolic activity of propionate-producing microbes (Ominski and Wittenberg, 2005; Martin et al., 2010). Because the formation of propionate consumes reducing equivalents (Equation 3), enhancing propionate production reduces the amount of metabolic $\mathrm{H}_{2}$ available for methanogenesis in the rumen. Ruminal $\mathrm{pH}$ also decreases with increasing NFC concentrations, which can inhibit the growth of methanogens and ciliate protozoa (van Kessel and Russell, 1996; Hegarty, 1999b). However, it can also reduce NDF digestibility. In general, decreasing the NDF:NFC ratio of ruminant diets can reduce the percentage of GEI lost as $\mathrm{CH}_{4}$ (Beauchemin et al., 2008; Chagunda et al., 2009). Very low $\mathrm{CH}_{4}$ emissions (2-3\% GEI) are reported from cattle fed low- (10-30\%) forage diets, such as beef finishing rations (Johnson and Johnson, 1995). Although in beef cattle research $\mathrm{CH}_{4}$ is often expressed as percentage of GEI, it should be expressed as $\mathrm{CH}_{4}$ per ADG or $\mathrm{CH}_{4}$ per kilogram of carcass yield in an analogous manner to the $\mathrm{CH}_{4} / \mathrm{ECM}$ approach for evaluating $\mathrm{CH}_{4}$ emissions in dairy cattle. If grain supplementation increases GEI and ADG even though $\mathrm{CH}_{4} / \mathrm{GEI}$ is unchanged, fewer days on feed will be required to reach target weight and less total $\mathrm{CH}_{4}$ will be emitted during the growing and finishing periods. Accordingly, whole-farm GHG inventory models usually predict lower GHG emissions from on-farm animal and manure emissions and from off-farm feed production with increased grain and byproduct feeding (Phetteplace et al., 2001; Lovett et al., 2006).

Although the word concentrates is broadly used many different feed ingredients can be incorporated into the nonforage portion of a ration. Hindrichsen et al. (2005) examined nonforage ingredients with lignified fiber, nonlignified fiber, pectin, fructans, sugar, or starch and found them to have differing effects on $\mathrm{DM}$ and NDF digestibilities, but not on $\mathrm{CH}_{4}$ emissions when expressed as grams of $\mathrm{CH}_{4}$ per kilogram of milk protein. Regression analysis of results from the same experiment (Hindrichsen et al., 2005) provided the following equation:

$$
\begin{gathered}
\mathrm{CH}_{4}(\mathrm{~g} / \mathrm{d})=91+50 \times \text { digested cellulose }(\mathrm{kg} / \mathrm{d}) \\
+40 \times \text { digested hemicellulose }(\mathrm{kg} / \mathrm{d})+24 \times \text { digested } \\
\text { starch }(\mathrm{kg} / \mathrm{d})+67 \times \text { digested sugars }(\mathrm{kg} / \mathrm{d}),
\end{gathered}
$$

which can be compared with the equation from Moe and Tyrrell (1979):

$$
\begin{gathered}
\mathrm{CH}_{4}(\mathrm{~g} / \mathrm{d})=33.0+104.6 \times \text { digested cellulose }(\mathrm{kg} / \mathrm{d}) \\
\quad+38.5 \times \text { digested hemicellulose }(\mathrm{kg} / \mathrm{d})+20.5 \\
\times \text { digested neutral detergent-soluble residue }(\mathrm{kg} / \mathrm{d}) .
\end{gathered}
$$

In both data sets, the digested cellulose and hemicellulose would be from combined forage and nonforage feed ingredients. In Moe and Tyrrell (1979), the neutral detergent-soluble residue fraction would include starch, sugars, silage acids, other organic acids, and the pectins and fructans not precipitated in NDF. Both equations clearly show that starch generates less $\mathrm{CH}_{4}$ than hemicellulose or cellulose per unit digested. The high coefficient for sugars in Hindrichsen et al. (2005) may reflect the stimulatory effect of sugars on fiber digestion.

The difference in $\mathrm{CH}_{4}$ produced per unit of starch versus cellulose is not a function of their chemical composition; both are hydrolyzed to glucose before being fermented. In contrast, hemicellulose, as a mixture of 5 - and 6-C sugars, would be expected to result in a different VFA pattern and proportion of $\mathrm{CH}_{4}$ than starch or cellulose. Rather than a chemical basis for the difference in $\mathrm{CH}_{4}$ production between starch, hemicellulose, and cellulose, the difference appears to be a function of the microbial species that degrade and ferment the majority of each substrate (Hungate, 1966; Baldwin and Allison, 1983). Thus, as microbial species adapt to changing dietary substrates and rumen conditions, patterns of VFA and $\mathrm{CH}_{4}$ production will change. Improving our understanding of the interrelationships between substrate availability and microbial maintenance and growth that affect overall rumen fermentation will lead to better predictions of $\mathrm{CH}_{4}$ generation and identification of opportunities to manipulate fermentation and reduce $\mathrm{CH}_{4}$ production. The observation that $\mathrm{CH}_{4}$ production is influenced by associative factors between nutrient fractions in the diet implies that $\mathrm{CH}_{4}$ can only be predicted for the diet or ration, not for the individual feed ingredients, which is analogous to the prediction of $\mathrm{NE}_{\mathrm{L}}$ or MP (NRC, 2001).

Forage Quality, Species, Harvesting, and Storage. Leng (1993) estimated that $75 \%$ of global ruminant $\mathrm{CH}_{4}$ emissions came from ruminants grazing low-quality feeds. Increasing the quality of the feed is an overarching concept related to feed efficiency and animal productivity, which can decrease $\mathrm{CH}_{4}$ emissions per unit of product. Increasing forage quality is favorably received by livestock farmers because feeding high-quality forages is central to good farming practice and often increases profitability (Waghorn 
and Clark, 2006). Forage quality can be improved by harvesting or grazing less mature forages, selection of genetic strains or species that have superior digestibility (e.g., brown midrib corn and sorghum), and proper storage, especially ensiling, to conserve digestible nutrient content, improve dietary utilization, and increase feed efficiency. In general, better-quality forages will contain a greater proportion of NSC to NDF or the NDF will be less lignified (Moss et al., 2000; Boadi et al., 2004).

Several studies have compared different forages in terms of $\mathrm{CH}_{4}$ emissions (McCaughey et al., 1999; Boadi et al., 2002, 2004; Boadi and Wittenberg, 2002; Robertson and Waghorn, 2002; van Dorland et al., 2007; O'Neill et al., 2012). The diets compared legumes versus grasses, stage of maturity, and grazed versus harvested forages. However, some comparisons were confounded with other dietary changes to maintain energy density or nitrogen intakes. A comprehensive evaluation of the effect of forage quality on $\mathrm{CH}_{4}$ emissions requires an approach that considers diet composition and level of intake. In essence, this has been done in the research to develop $\mathrm{CH}_{4}$ prediction equations (Moe and Tyrrell, 1979; Mills et al., 2003) and in the meta-analysis of Archimède et al. (2011), which accounted for intake and NDF digestibility (discussed in the previous section).

The effects of forage preservation on $\mathrm{CH}_{4}$ production have not been studied at length. The ensiling process results in fermentation of the forages, which can reduce digestion in the rumen (Boadi et al., 2004). Cows fed either a partial or total mixed ration with ensiled forages with $\mathrm{OM}$ digestibilities $>80 \%$ had similar $\mathrm{CH}_{4} / \mathrm{ECM}$ as cows consuming high-quality pasture with similar digestibilities (Robertson and Waghorn, 2002; O'Neill et al., 2012). When expressed as percentage of GEI, ensiled forages have been shown to produce less $\mathrm{CH}_{4}$ than dried forages (Sundstol, 1981). Some evidence exists that maize and whole-crop small-grain silages will yield less $\mathrm{CH}_{4}$ than grass silage, which likely reflects differences in carbohydrate composition and digestibility, but a need still exists for direct in vivo comparisons and whole-farm GHG analyses for all of these situations (Beauchemin et al., 2008). Different additives and inoculants have been added to silage with limited success in reducing $\mathrm{CH}_{4}$ production (Boadi et al., 2004).

Feed Processing. Feed processing reduces the particle size distribution of the feed and alters the rates of fermentation and passage of the particles, with the benefit depending on the feed. Particles that are too small can pass undigested out of the rumen and will not increase the amount fermented (Russell and Hespell, 1981). Processing forages by grinding, chopping, or pelleting will decrease rumen NDF digestibility and can decrease $\mathrm{CH}_{4}$ emissions as a result of increased passage rate (Table 1; Johnson et al., 1996; Moss et al., 2000) with decreased acetate:propionate ratios (Van Nevel and Demeyer, 1996). This effect is not usually evident with restricted intakes, but at high levels of intake $\mathrm{CH}_{4}$ reductions of 20 to $40 \%$ per unit of DM could be achieved (Johnson and Johnson, 1995). Pelleting can decrease $\mathrm{CH}_{4}$ production to a greater extent than chopping, but the effect of pelleting is most pronounced with low-quality forages (Hironaka et al., 1996). Also, the $\mathrm{CH}_{4}$ reductions may not be great enough to justify the extra energy expenditure and the likely increased associated GHG production required to pellet the feed (Hironaka et al., 1996). Fine grinding of forages has proven to be uneconomical due to the greater incidence of acidosis associated with deficient effective NDF and decreased milk fat concentration (Boadi et al., 2004). Last, the acetate:propionate ratio has been decreased through alkali treatment of cereal straw (Van Nevel and Demeyer, 1996), a strategy that could reduce $\mathrm{CH}_{4}$ by $10 \%$ (Johnson et al., 1996). Experimentation with feeding alkali-treated straw to sheep found $\mathrm{CH}_{4}$ per unit of apparently digested $\mathrm{OM}$ to be reduced, and the volume of $\mathrm{CH}_{4}$ produced per animal was significantly increased due to increased intakes (Moss et al., 1994). If alkali treatment of poor-quality forages were to be used for feeding cattle and digestibility were increased, $\mathrm{CH}_{4}$ / ECM or $\mathrm{CH}_{4}$ per ADG would be expected to decrease.

Processing grains by grinding, rolling, or flaking can increase rumen fermentation and decrease the amount passing to the intestines (Table 1). Extensive rolling of barley increased DMI and maximized ruminal and postruminal digestibility of starch (Yang et al., 2001). Heat treatment through pelleting, flaking, extruding, and toasting can change the degradation rates of protein and carbohydrates and decrease the acetate:propionate ratio (Van Nevel and Demeyer, 1996) but the relationship with $\mathrm{CH}_{4}$ emissions depends on the feed as well as composition of the total diet and intake.

Overall, processing could have mixed effects. Processing forages alters rumen fermentation and decreases rumen NDF digestibility. If NDF is digested in the hindgut or in manure storage, no net change in whole-farm $\mathrm{CH}_{4}$ emissions will occur. Conversely, processing grains increases rumen DM and starch digestibility (Firkins et al., 2001), with more $\mathrm{CH}_{4}$ being produced from rumen fermentation than if starch were digested in the small intestine, assuming no negative effects on fiber digestion. Processing that improves DM digestibility will reduce $\mathrm{CH}_{4} / \mathrm{ECM}$ by increasing energy available for productive purposes and diluting $\mathrm{CH}_{4}$ associated with maintenance. In contrast, processing that decreases digestibility and $\mathrm{CH}_{4}$ per day per head is not desirable, as more feed inputs will be required to produce the same amount of milk. 
Lipid and FA Supplementation. Lipid supplementation is an extensively researched enteric $\mathrm{CH}_{4}$ mitigation strategy, and several reviews are available on this topic (Giger-Reverdin et al., 2003; Beauchemin et al., 2008; Eugene et al., 2008). Climate Change Central (2012) in Alberta, Canada already recognizes oil supplementation as a mitigation strategy under their protocols. The effect of dietary lipids on $\mathrm{CH}_{4}$ production is dependent on the source, FA profile, inclusion rate (\% of DMI), and diet composition (Beauchemin et al., 2007b; 2008). The form of the lipid supplement affects its availability in the rumen, and this appears to be more important than the FA profile (Beauchemin et al., 2009).

In vitro, lipid additives suppress ciliate protozoa (Dohme et al., 2000) and methanogen populations in the rumen (Machmüller and Kreuzer, 1999) by differing modes of action, depending on the primary FA (Dohme et al., 2001). They decrease OM and fiber degradability and reduce fermentable substrate (Van Nevel and Demeyer, 1996; Dong et al., 1997; Dohme et al., 2001; McGinn et al., 2004), which means less $\mathrm{CH}_{4}$ production but is not a desirable effect in itself. Biohydrogenation of unsaturated FA can be an alternative sink for $\mathrm{H}_{2}$, but this is trivial compared with methanogenesis (Johnson and Johnson, 1995; Hegarty, 1999a). In animals that are not rumen-fill limited but eat to meet energy requirements, lipids create a dilution effect because they replace fermentable carbohydrates in the energy supply. Also, they often reduce DMI. Finally, rumen inert or protected fats (such as calcium soaps) do not show the same effects as other lipid sources (Dohme et al., 2000). In a meta-analysis by Beauchemin et al. (2008) using 33 treatments, each $1 \%$ addition of fat to the diet resulted in a $5.6 \%$ reduction in $\mathrm{CH}_{4}(\mathrm{~g} / \mathrm{kg}$ of DMI) up to $36 \%$. Another meta-analysis concluded that lipid supplementation to dairy cows reduces daily $\mathrm{CH}_{4}$ production by $0.305 \mathrm{~g} / \mathrm{kg}$ of DMI for each $1 \%$ increase in ration ether extract $(\mathbf{E E})$, and mainly as a consequence of lower DMI (Eugene et al., 2008). The effect of lipid composition or type was not evaluated.

Given our focus on $\mathrm{CH}_{4} / \mathrm{ECM}$, we conducted a metaanalysis on the effects of lipid supplementation on $\mathrm{CH}_{4}$ emissions. Eleven studies were identified in the published literature with different sources of lipid (whole seed, crushed seed, oils, calcium salts of FA, and FFA), and include the work of Andrew et al. (1991), Holter et al. (1992), Johnson et al. (2002), Dohme et al. (2004), Odongo et al. (2007b), Martin et al. (2008), Beauchemin et al. (2009), Hristov et al. (2009, 2011) Grainger et al. (2010), Mohammed et al. (2011), and Hollmann et al. (2012). Most of the studies were designed to compare different lipid sources; only 1 study used the same supplement at different levels (Hollmann et al., 2012). Often, more than 2 ingredients were different between treatments and nutrients other than EE varied between treatments within the same study. Five studies used open-circuit respiratory chambers, 1 study used hoods, and 5 studies used $\mathrm{SF}_{6}$ methodology to measure $\mathrm{CH}_{4}$ emissions. Measurement method was a significant effector of observed $\mathrm{CH}_{4} / \mathrm{ECM}$ (data not shown). The data were analyzed using the following model:

$$
\mathrm{y}_{\mathrm{k}}=\beta_{0}+\mathrm{s}_{\mathrm{i}}+\beta_{\mathrm{j}} \times \mathrm{ee}+\text { error }_{\mathrm{k}},
$$

where $\mathrm{y}_{\mathrm{k}}=\mathrm{CH}_{4} / \mathrm{ECM}$ and are the treatment means $(\mathrm{k}=1$ to 35$), \beta_{0}=$ a common intercept across studies, $\mathrm{s}_{\mathrm{i}}=$ the random study effect ( $\mathrm{i}=1$ to 11$), \beta_{\mathrm{j}}=$ the regression coefficient for the jth lipid source $(\mathrm{j}=$ 1 to 4 ), and ee = the EE content of the ration. Lipid sources were identified as either rumen inert (calcium salts of FA or stearic acid), oils (medium-chain FA or vegetable oils), seeds (whole, crushed, or extruded), or endogenous lipids in feedstuffs (control treatments). The standard error of $\mathrm{CH}_{4}$ emissions across studies varied over a 3 -fold range, and this variation was used to weight studies accordingly using the inverse of the reported standard error for $\mathrm{CH}_{4}(\mathrm{~g} / \mathrm{d})$. The variance component due to the interaction between study effect and EE content was very small compared with the study effect and thus was removed from the model to improve parameter estimates.

Observed treatment means of $\mathrm{CH}_{4} / \mathrm{ECM}$ as a function of ration EE content can be seen in Figure 4a, with lines connecting the individual treatment means within a study. Overall, a trend for decreasing $\mathrm{CH}_{4} / \mathrm{ECM}$ could be seen as EE increased, although some studies showed little change (I, J, and $\mathrm{K}$ ) or an increase (D and $\mathrm{F}$ ). The differences between studies are large, and may be attributable to measurement method, diet, and animal characteristics, and other experimental variation, and all of these are captured in the study effect in the statistical analysis. After accounting for the study effect, the results show that increasing EE content in the ration reduced $\mathrm{CH}_{4} / \mathrm{ECM}$, and that significant differences existed in the interaction between lipid sources and EE content (Figure 4b). Each percentage unit of ration EE from inert, seed, oil, and endogenous lipid sources decreased $\mathrm{CH}_{4} / \mathrm{ECM}$ by $0.78 \pm 0.20,0.71 \pm$ $0.20,1.12 \pm 0.20$, and $1.01 \pm 0.38 \mathrm{~g} / \mathrm{kg}$, respectively. The slopes of inert and seed lipid sources were not significantly different from each other $(P>0.48)$, but differed significantly from the slope of oil lipid source $(P<0.006$ and $<0.002$, respectively). The slope of endogenous lipid source was intermediate between that of inert and seed sources versus oil sources, and not 
significantly different from any treatment $(P>0.17$ to 0.51 ). The endogenous lipids in feedstuffs contain greater concentrations of MUFA and PUFA than SFA. The intermediate slope for endogenous lipid diets may be indicative of an effect of FA composition on rumen function and $\mathrm{CH}_{4}$ production.

Different lipid sources may affect $\mathrm{CH}_{4}$ emissions by altering DMI and this could affect $\mathrm{CH}_{4} / \mathrm{ECM}$. Previous reviews have observed a reduction in DMI with lipid supplementation (Chilliard, 1993; Allen, 2000; Beauchemin et al., 2008). In this analysis, the best fit model for DMI was $y_{k}=s_{i}+\beta_{j}+\beta_{j} \times$ ee + error $_{k}$, with separate intercepts and slopes for each lipid source. Analysis of the effect of lipid source and ration EE content showed that inert and endogenous lipid sources did not affect DMI $(\mathrm{kg} / \mathrm{d}$; Figure $4 \mathrm{c} ; P>0.85$ and $P>$ 0.77 , respectively). However, oil sources (vegetable oils and medium-chain FFA) significantly reduced DMI by $1.51 \pm 0.40 \mathrm{~kg}$ per percentage unit increase in ration EE (Figure 4c; $P<0.001$; intercept $=28.0 \pm 3.10$ ). Seeds also reduced DMI by $0.90 \pm 0.52 \mathrm{~kg}$ per percentage unit increase in ration EE (Figure 4c; $P<0.09$, intercept $=25.8 \pm 3.47$ ). This effect of ration $\mathrm{EE}$ for seeds followed a quadratic pattern, with reductions in DMI occurring at ration EE approximating 7\% DM (Figure 4c). The greater variation observed with seeds is reasonable, given that these treatments included whole, crushed, and extruded seeds.

In summary, increasing ration $\mathrm{EE}$ with endogenous lipid in feedstuffs, inert lipids, or seed sources reduces enteric $\mathrm{CH}_{4} / \mathrm{ECM}$, and it appears that this is achieved by dilution of the fermentable carbohydrates in the DMI and potentially reduced DMI. No difference existed in $\mathrm{CH}_{4} / \mathrm{ECM}$ between the inert, seed, or endogenous feed sources of lipids. Some seeds, vegetable oils, and medium-chain FFA further reduced $\mathrm{CH}_{4} / \mathrm{ECM}$, but it appears that this was largely achieved at the expense of reduced DMI, which could be detrimental to energy balance and milk yield over longer periods of time. Vegetable oils and medium-chain FA are known to alter rumen function and decrease NDF digestibility. Whether these lipid sources reduce enteric $\mathrm{CH}_{4} / \mathrm{ECM}$ by this mechanism cannot be ascertained in this analysis, as rumen digestibilities were not measured. However, it is supported by subsequent research of Hollmann et al. (2013) that demonstrated reduced DMI and total-tract NDF digestibility with increasing dietary inclusion of coconut oil. Also, most of the studies used in this analysis were short-term feeding trials (2 to $5 \mathrm{wk}$ ), with the exception of Grainger et al. (2010; 12 wk). Future research in this area should focus on dose-response relationships by using multiple levels of lipid supplementation and longer-term trials where energy balance can be determined (Beauchemin et al., 2008; Grainger et al., 2008b; Martin et al., 2008). Furthermore, the effect of lipid supplementation on emissions of $\mathrm{CH}_{4}$ and other GHG must be evaluated on a whole-farm basis. If lipids reduce fiber digestibility, then more $\mathrm{CH}_{4}$ may be emitted from the manure during storage and anaerobic fermentation (Hristov et al., 2013).

Typically, lactating cow rations contain 4 to $5 \%$ EE, with fat supplementation increasing levels to 5 to $7 \%$ DM. Current recommendations are for ration EE to not exceed 6 to $7 \%$ DM (NRC, 2001). With decreases in enteric $\mathrm{CH}_{4} / \mathrm{ECM}$ of 0.71 to $1.21 \mathrm{~g} / \mathrm{kg}$ for each percentage of ration $\mathrm{EE}$ and typical $\mathrm{CH}_{4}$ emissions of 5 to $25 \mathrm{~g} / \mathrm{kg}$ of ECM, a $2 \%$ increase in ration EE would be expected to decrease $\mathrm{CH}_{4}$ approximately $10 \%$. This reduction is comparable with the low end of the range of 10 to $25 \%$ reductions given on a $\mathrm{CH}_{4} / \mathrm{DM}$ in Beauchemin et al. (2008). Reductions on a $\mathrm{CH}_{4} / \mathrm{ECM}$ basis should be less than reductions on a $\mathrm{CH}_{4} / \mathrm{DM}$ basis, given the strong, positive relationship between DMI and ECM. The effects of fat supplementation on milk and milk component yields are variable, and depend on the nutrient composition of the basal diet, FA composition of the endogenous and supplemental lipids, and stage of lactation as well the amount of fat supplemented (NRC, 2001). Excellent reviews on this topic can be found in Chilliard (1993), Jenkins (1997), and Schroeder et al. (2004).

Summary of Nutrition and Feeding Management Strategies. Many of these enteric $\mathrm{CH}_{4}$ mitigation strategies are mechanistically geared toward enhancing the propionate:acetate ratio from fermentation. Although methanogens are a crucial part of the rumen ecology, $\mathrm{CH}_{4}$ formation should be minimized and the yield of VFA maximized. The potential for reducing $\mathrm{CH}_{4} / \mathrm{ECM}$ through nutrition and feeding management is modest (Figure 5) and will be mostly achieved by approaches that improve feed efficiency (Figure 6). Feeding nonstructural or starchy carbohydrates, highquality forages at greater intake levels, or optimally processing the forages can reduce enteric $\mathrm{CH}_{4} / \mathrm{ECM}$ emissions by 5 to $15 \%$ (Table 1; Figure 5 ).

It may be possible to combine some of the feeding and nutritional management approaches to reduce enteric $\mathrm{CH}_{4} / \mathrm{ECM}$ (e.g., forage genetics and improved forage quality via management). Some of the approaches are redundant with respect to mechanisms and outcome (e.g., feeding more concentrate and reducing rumen $\mathrm{pH}<5.5)$. Some result in reduced DMI, which reduces both $\mathrm{CH}_{4}$ and ECM, with no decrease or potentially increasing $\mathrm{CH}_{4} / \mathrm{ECM}$ (e.g., decreasing rumen $\mathrm{pH}<5.5$ or lipid feeding). Some approaches may lead to other undesirable outcomes, such as reduced feed efficiency, liver abscesses, and so on. With the redundancy in effects and the robust ability of the rumen microbes to 


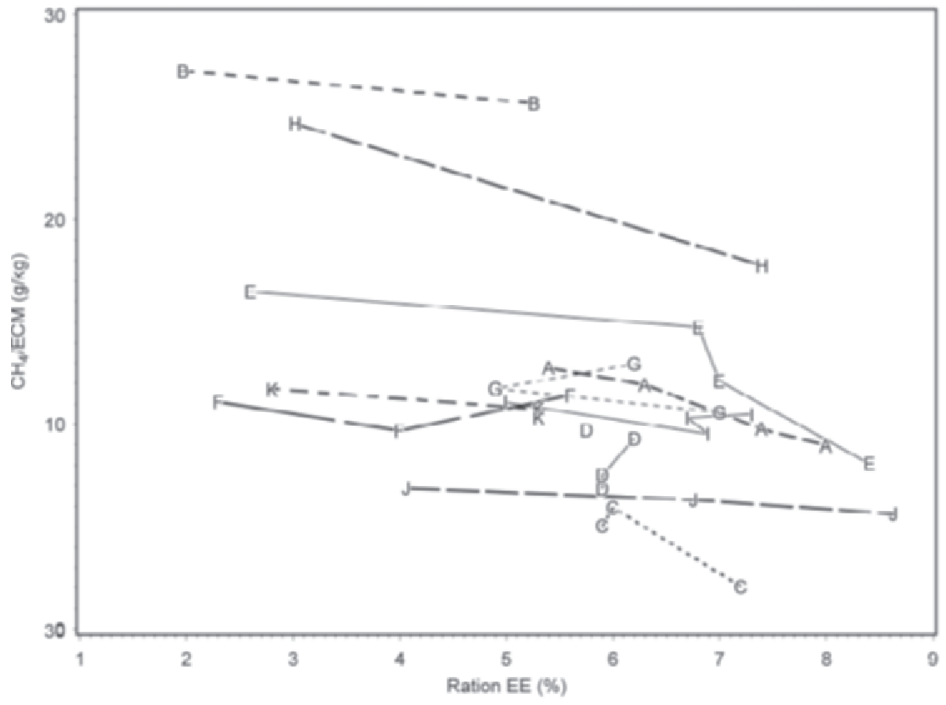

b)
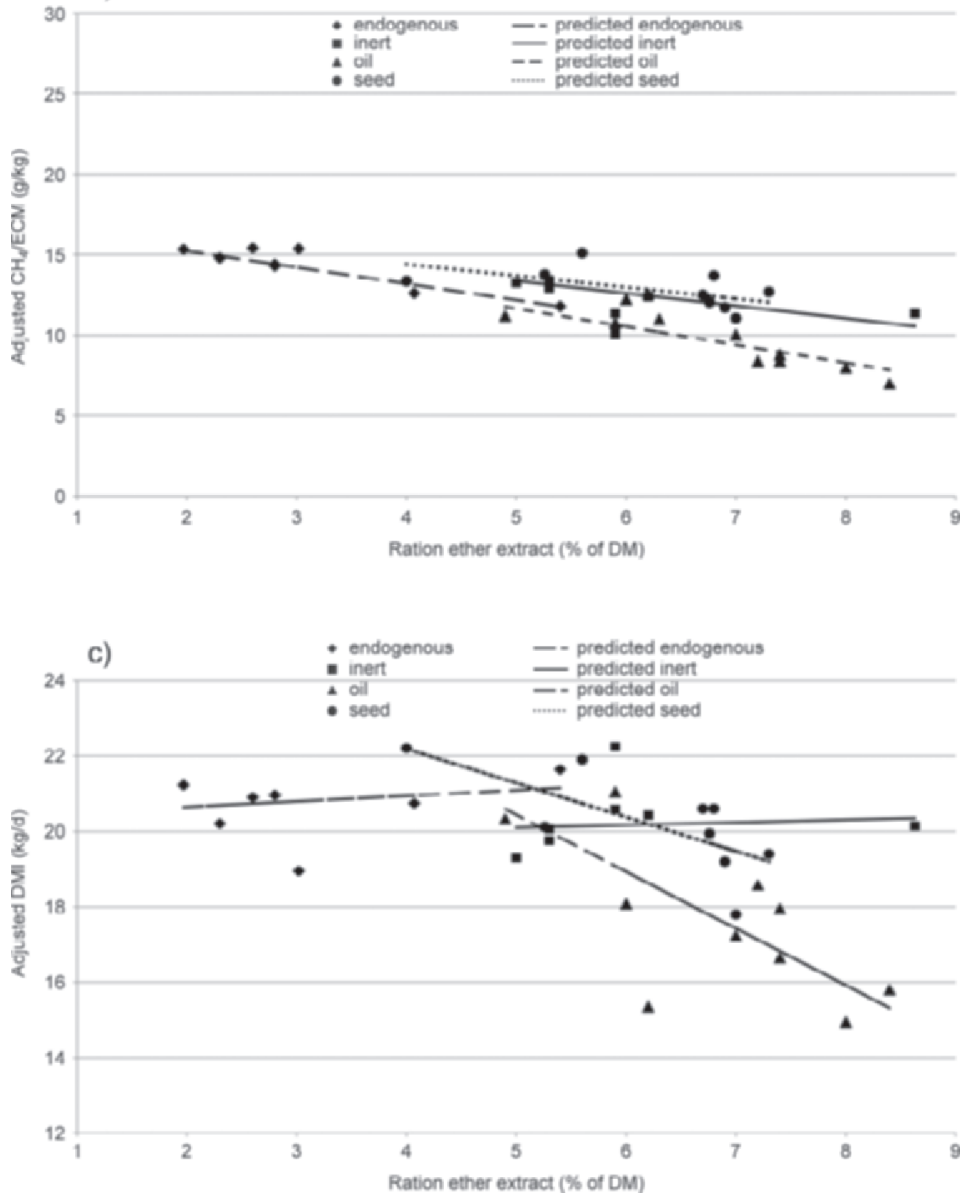

Figure 4. (a) Summary of enteric $\mathrm{CH}_{4}$ emissions per unit of ECM $\left(\mathrm{CH}_{4} / \mathrm{ECM}\right)$ as a function of ration ether extract (EE) content from 11 studies and 35 dietary treatments. Observed treatment means for each study are connected by lines. Study A: Hollmann et al. (2012), B: Grainger et al. (2010), C: Hristov et al. (2009), D: Hristov et al. (2011), E: Martin et al. (2008), F: Johnson et al. (2002), G: Dohme et al. (2004), H: Odongo et al. (2007a), I: Beauchemin et al. (2009) and Mohammed et al. (2011), J: Holter et al. (1992), and K: Andrew et al. (1991). (b) Predicted reductions in $\mathrm{CH}_{4} / \mathrm{ECM}$ for inert, seed, oil, and endogenous (nonsupplemented) sources of lipid. Intercept $=17.25 \pm 2.07 \mathrm{~g} / \mathrm{kg}$. Slopes for different lipid sources are given in the text. (c) Predicted reductions in DMI for inert, seed, oil, and endogenous (nonsupplemented) sources of lipid. Intercepts and slopes for different lipid sources are given in the text. 


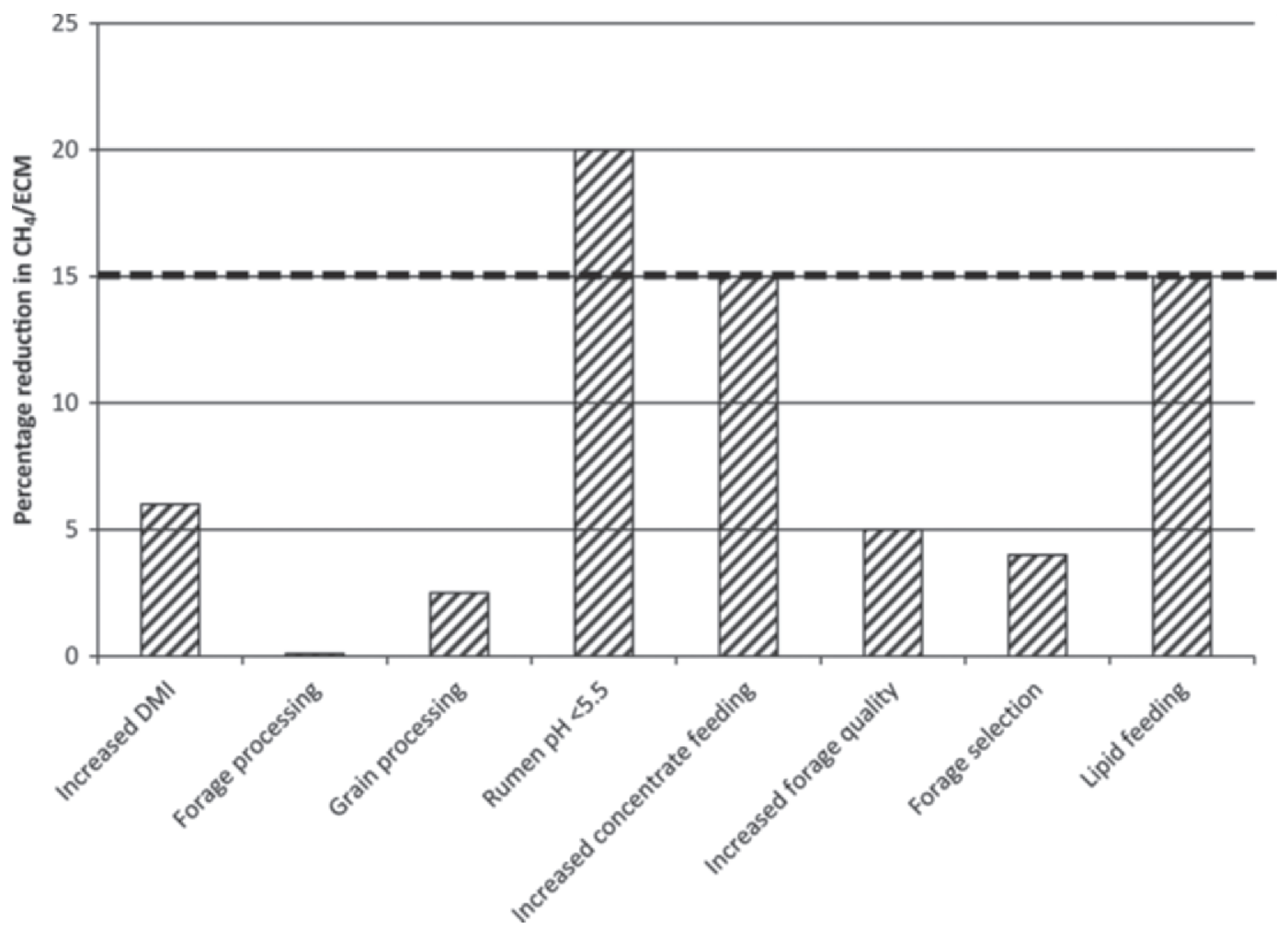

Figure 5. Feeding and nutritional approaches to reducing enteric $\mathrm{CH}_{4}$ emissions per unit of $\mathrm{ECM}\left(\mathrm{CH}_{4} / \mathrm{ECM}\right)$ range from 0 to $15 \%$ and are

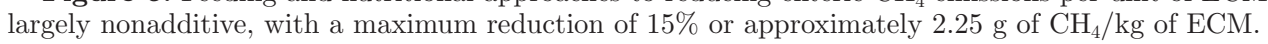

adjust to changing conditions through several mechanisms, responses to different nutritional approaches are expected to be significantly less than fully additive (Figure 5). The implementation of many of the feeding and nutritional approaches is limited to lactating dairy cattle rations for practical or economic reasons and, thus, the reductions in enteric $\mathrm{CH}_{4}$ would be less on a whole-herd basis than on an individual-cow basis.

\section{Rumen Modifiers: Feed Additives and Biological Control}

A wide variety of supplements exist that can be administered to reduce $\mathrm{CH}_{4}$, such as chemical inhibitors, organic acids, and plant secondary compounds. The mode of action depends on the specific additive, but can include direct inhibition of methanogens or methanogenesis, suppression of ciliate protozoa, or providing or stimulating a competitive pathway for $\mathrm{H}_{2}$ disposal. A wide variety of inhibitors have been studied, including halogenated $\mathrm{CH}_{4}$ analogs, coenzyme-M analogs, and proton-motive force uncouplers (Czerkawski and Breckenridge, 1972; Martin and Macy, 1985).

In vitro, many additives and inhibitors suppress methanogenesis by 60 to $100 \%$ (Table 2). When these additives are fed to animals, however, the reduction in

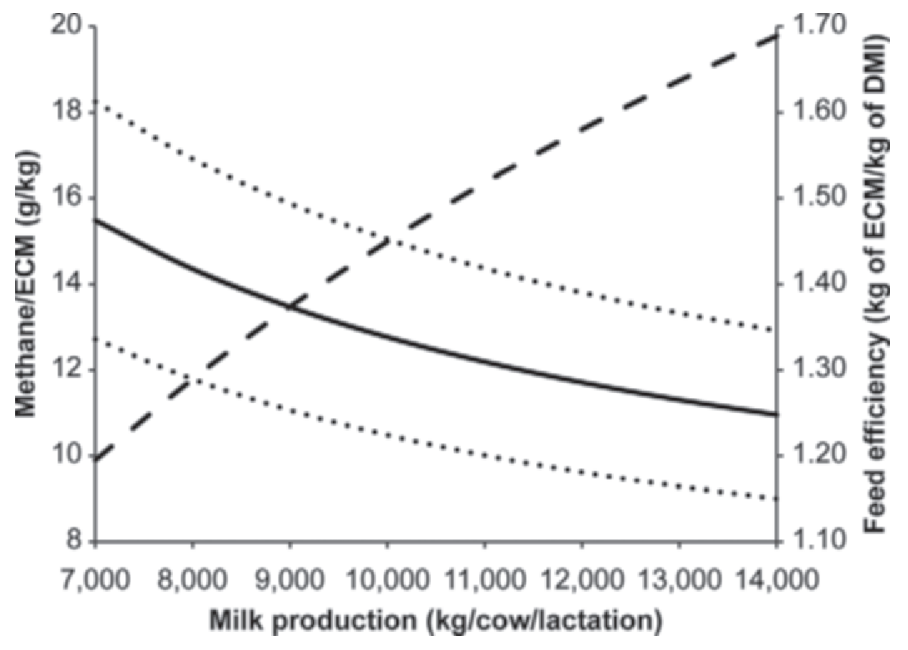

Figure 6. Enteric $\mathrm{CH}_{4}$ emissions per unit of $\mathrm{ECM}\left(\mathrm{CH}_{4} / \mathrm{ECM}\right.$; solid and dotted lines, primary axis) decreases with increasing productivity and increasing feed efficiency (dashed line, secondary axis) and can vary by more than $\pm 20 \%$. Estimates do not consider improved diet quality or decreased digestibility for high-producing cows, which would further lower enteric $\mathrm{CH}_{4} / \mathrm{ECM}$. Predictions of $\mathrm{CH}_{4}$ production were calculated as described in the text at $\mathrm{Ym}=5.6 \%$ GEI (solid line) and at $\mathrm{Ym}=4.6$ and $6.6 \%$ (dotted lines, primary axis), where $\mathrm{Ym}=\mathrm{CH}_{4}$ as a percentage of gross energy intake (GEI). 
$\mathrm{CH}_{4}$ emissions has been either not evident or transient $(<30 \mathrm{~d}$; Table 3). Basic ecological principles need to be kept in mind when targeting microbial populations. With the incredible diversity of ruminal microbes, it is very likely that the removal or suppression of one group will result in another group adapting to fill its niche (Hungate, 1966; Czerkawski, 1986; Weimer, 1998). Recent studies indicate that $\mathrm{CH}_{4}$ emission reductions resulting from short- and long-term defaunation do not correlate with the relative abundance of methanogens measured by quantitative PCR (Mosoni et al., 2011; Morgavi et al., 2012). In fact, Mosoni et al. (2011) reported that although defaunation reduced $\mathrm{CH}_{4}$ emissions, ruminal methanogen density increased 10-fold. Second, if methanogenesis is reduced or eliminated, another route must exist for hydrogen disposal, or else rumen hydrogen concentrations will rise and potentially inhibit fermentation (Weimer, 1998). Ideally, this hydrogen or electron sink would result in the production of a compound that can be absorbed and metabolized by the animal so that the energy is not lost (Brown et al., 2011).

Several reviews have summarized the potential of using rumen modifiers on a qualitative basis (Van Nevel and Demeyer, 1996; Boadi et al., 2004, Beauchemin et al., 2008; Martin et al., 2010; Hristov et al., 2013). Many of these $\mathrm{CH}_{4}$ reduction strategies have not been evaluated to determine the sustained effects of the additive, the appropriate in vivo dose, or the economics of the approach in terms of effect on milk production, all of which are important considerations for large-scale implementation. To date, no feed additives have demonstrated sustained reduction in $\mathrm{CH}_{4}$ emissions without a negative effect on milk production in lactating dairy cattle other than the use of nitrate as an alternative electron acceptor, which has the issue of animal toxicity (Table 3; van Zijderveld et al., 2011). Successful biological control to reducing $\mathrm{CH}_{4}$ emissions has been achieved with defaunation in sheep, goats, and growing cattle, but has had mixed effects on animal growth (Jouany, 1996). Given the extensive review of these strategies by others (above) and the focus in this review on quantitative reductions in $\mathrm{CH}_{4}$ / ECM, rumen modifiers will not be discussed further. At this time, greater opportunities exist in reducing enteric $\mathrm{CH}_{4}$ emissions from dairy cattle through nutrition, feeding management, genetic selection, and improvements in herd health and productivity than with the use of feed additives as rumen modifiers (Waghorn, 2011). However, research should continue in identifying and developing rumen modifiers because of its value in elucidating rumen microbial interactions and increasing our knowledge of rumen function.

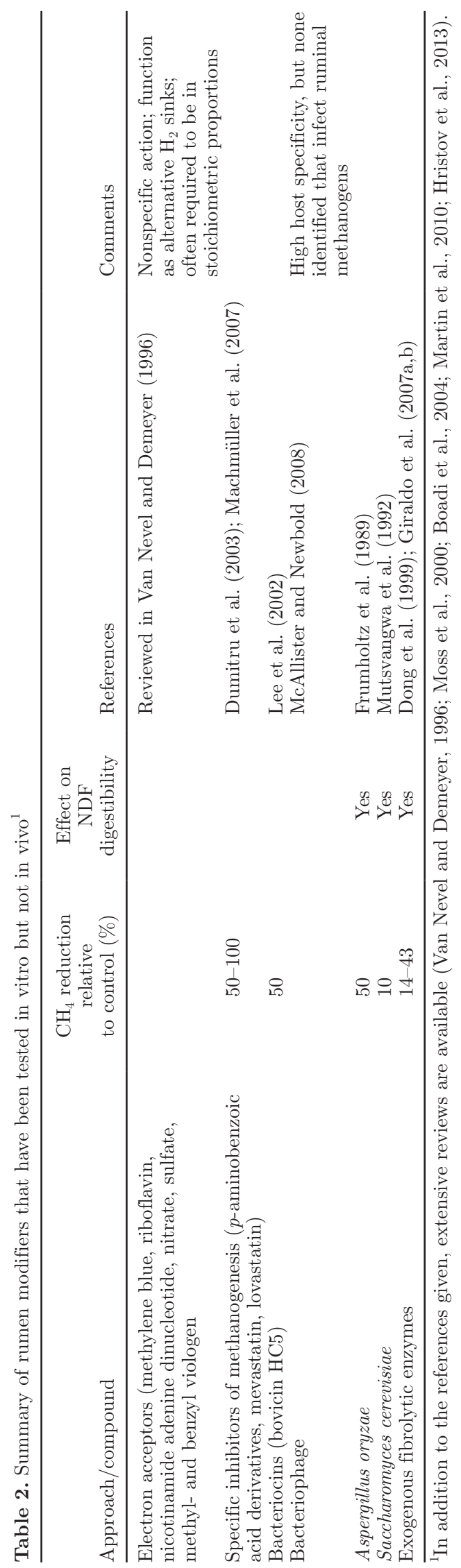




\section{Genetic Approaches to Increasing Productivity and Reducing $\mathrm{CH}_{4} / \mathrm{ECM}$}

Differences between individual animals in plant selection during grazing, rumen digesta retention rates, and host-microbe interactions may be heritable and thus amenable to genetic selection for animals with lesser enteric $\mathrm{CH}_{4}$ emissions on a per-day or per-DMI basis (Pinares-Patiño et al., 2007; Clark, 2013; Ross et al., 2013). Poor repeatability of some $\mathrm{CH}_{4}$ measurements and high within-animal variation may limit selection on this basis (Pinares-Patiño et al., 2007; Vlaming et al., 2008). Although genetic selection for reduced $\mathrm{CH}_{4}$ emissions has been used in sheep and beef cattle (Hegarty and McEwan, 2010; Clark, 2013; PinaresPatiño et al., 2013), the relationship between $\mathrm{CH}_{4}$ emissions and animal growth has not been evaluated. Also, although metagenomic tools are being developed that may accelerate the selection process (Ross et al., 2013), to date no published evidence exists supporting the potential for this approach in dairy cattle, and by comparison with genetic selection for residual feed intake, it is likely to take more than $10 \mathrm{yr}$ to develop.

Widespread consensus exists that increasing the productivity of an animal will decrease the proportion of $\mathrm{CH}_{4}$ produced per unit of product (Johnson et al., 1996; Moss et al., 2000; Boadi et al., 2004; Beauchemin et al., 2008; Pinares-Patiño et al., 2009; Clark, 2013). The Environmental Protection Agency has clearly stated that "Improving livestock productivity so that less $\mathrm{CH}_{4}$ is emitted per unit of product is the most promising and cost-effective technique for reducing emission" (EPA, 2005) and is in concordance with global efforts (Global Research Alliance on Agricultural Greenhouse Gases; Shafer et al., 2011). More-efficient dairy cows will produce more milk relative to the amount of feed ingested and energy lost as $\mathrm{CH}_{4}$ (Figure 6). Production efficiency can be improved by genetic selection and management practices that address not only nutrition and feeding, but also reproduction, heat stress tolerance, disease incidence, culling rates, and heifer replacement programs. Although the effects of genetic selection and management improvements are commonly examined on an individual-cow basis, from a $\mathrm{CH}_{4}$ mitigation perspective, it is more important to view them on a herd-productivity basis. Genetic selection and management approaches detailed below have the potential to increase yield while reducing the number of replacement animals needed, contributing to reduced $\mathrm{CH}_{4}$ production by the herd and increased ECM.

Genetic Selection for Yield and Energetic Efficiency. Tremendous progress in genetic selection of dairy cattle has been made over the past $60 \mathrm{yr}$ and, combined with improvements in animal management, has resulted in a $400 \%$ increase in North American milk yields (Hansen, 2000; VanRaden, 2004; Shook, 2006; Capper et al., 2009). This increase in milk yield is paralleled by a corresponding $64 \%$ reduction in the US dairy cattle population and $57 \%$ reduction in $\mathrm{CH}_{4}$ emitted per unit of product (Capper et al., 2009). Genetic selection has also increased milk yields in other countries and regions, including Argentina, Chile, Australia, New Zealand, Israel, and the European Union (Van Raden, 2004; FAOSTAT, 2014). Although remarkable gains have been made in milk yield through genetic selection, no indication exists that the genetic potential for milk yield is approaching a maximum (Cole and VanRaden, $2011)$. Cow-to-cow variation is large $(\mathrm{SD}= \pm 2,500 \mathrm{~kg} /$ lactation), indicating that substantial heterogeneity still exists in the population to permit selection.

On an individual-cow basis, $\mathrm{CH}_{4} / \mathrm{ECM}$ can be reduced by 3 different approaches. The first is to increase milk yield per cow with correspondingly smaller increases in DMI, which dilutes the maintenance energy costs of the cow and increases gross energy efficiency. The second is to reduce body size without reducing yields of milk and milk components, which also has the effect of increasing gross energy efficiency, but by decreasing the maintenance energy requirements of the animal. The third is to select for residual feed intake or residual solids production, which are both measures of feed efficiency. These approaches are all based on the concept that maintenance energy is a fixed cost and a function of body size. Because $\mathrm{CH}_{4}$ production is proportional to the energy intake of the animal, reducing the proportion of energy utilized for maintenance while maintaining or increasing milk yield would decrease $\mathrm{CH}_{4} /$ ECM.

Genetic selection over the past 6 decades has been based largely on the first approach, with increasing yields of milk and milk fat. Selection for yields of milk protein has been implemented over the past 2 decades in the US dairy industry. Reductions in enteric $\mathrm{CH}_{4} / \mathrm{ECM}$ with genetic selection for milk yield follow a diminishing returns pattern (Figure 6). Predictions are based on a $680-\mathrm{kg}$ Holstein cow producing milk with $3.7 \%$ milk fat and $3.0 \%$ true protein. Predictions for other breeds will follow a similar pattern, albeit at different milk yields. Dry matter intake was calculated using Equation 1-2 (NRC, 2001; page 4). Methane production was calculated at 3 levels of GEI that are within the range observed in the published literature and currently being used for US regional estimates by the Environmental Protection Agency (Kebreab et al., 2008; EPA, 2011b). Increases of $100 \mathrm{~kg}$ of milk per lactation are predicted to result in a $7.3 \%$ decrease in $\mathrm{CH}_{4} / \mathrm{ECM}$ at a $7,000-\mathrm{kg}$ 


\begin{tabular}{|c|c|c|c|}
\hline Approach/compound & $\begin{array}{l}\mathrm{CH}_{4} \text { reduction } \\
\text { relative } \\
\text { to control }\end{array}$ & $\begin{array}{l}\text { Transient or } \\
\text { sustained effect } \\
(>30 \mathrm{~d})^{2}\end{array}$ & $\begin{array}{l}\text { Animal } \\
\text { toxicity }\end{array}$ \\
\hline Monensin & 4 to $10 \%$ & $\begin{array}{l}\text { Sustained in one } \\
\text { study; transient in the } \\
\text { rest of the studies }\end{array}$ & $\begin{array}{l}\text { None at } \\
\text { recommended } \\
\text { feeding levels }\end{array}$ \\
\hline Monensin controlled-release capsules & $0 \%$ & No effect & None \\
\hline Halogenated $\mathrm{CH}_{4}$ analogs & 80 to $100 \%$ & $\begin{array}{l}\text { Sustained in } 1 \text { study; } \\
\text { transient in the rest of } \\
\text { the studies }\end{array}$ & Yes \\
\hline $\begin{array}{l}9,10 \text {-Anthraquinone } \\
\text { Dicarboxylic acids }\end{array}$ & $\begin{array}{l}50 \% \\
50 \text { to } 75 \% \text { in } 1 \text { study; } \\
0 \% \text { in others }\end{array}$ & Transient & $\begin{array}{l}\text { Tissue residues } \\
\text { Possible sodium } \\
\text { toxicity if sodium } \\
\text { salt is used }\end{array}$ \\
\hline
\end{tabular}

Essential oils

0 to $19 \%$

Saponins

0 to $16 \%$

Condensed tannins

Nitrate and sulfate

12 to $46 \%$ in sheep and goats; $0 \%$ in bee cattle: 0 to $26 \%$ in dairy cattle

16 to $57 \%$

Sustained (1 study)
References

Callaway et al. (2003); Guan et al. (2006); Odongo et al. (2007a); Beauchemin et al. (2008)

Moate et al. (1997); Grainger et al. 2008a); Waghorn et al. (2008)

McCrabb et al. (1997); Moss et al. (2000); Boadi et al. (2004); McAllister and Newbold (2008) Kung et al. (2003)

Moss et al. (2000); Boadi et al. 2004); McGinn et al. (2004);

Mohammed et al. (2004b);

Beauchemin and McGinn (2006b) Wallace et al. (2006); McAlliste and Newbold (2008); Foley et al. (2009); Molano et al. (2008)

Beauchemin and McGinn (2006b)

Hess et al. (2004); Santoso et al. (2004); Lila et al. (2005); Pen et al. (2007); Holtshausen et al. (2009); Wang et al. (2009)

Woodward et al. (2002); Carulla et al. (2005); Hess et al. (2006); Beauchemin et al. (2007a); de Oliveira et al. (2007); Animut et al. (2008); Grainger et al. (2009) Sar et al. (2004); van Zijderveld et al. $(2010,2011)$

Anderson et al. (2004); Anderson et al. (2006); Gutierrez-Bañuelos et al. (2007); Anderson et al. (2008); Brown et al. (2011)

McGinn et al. (2004) Hristov et al. (2010); Chung et al. (2011) Takahashi et al. (1997) Mohammed et al. (2004a);

Fonty et al. (2007)

Comments

$\mathrm{CH}_{4}$ reductions achieved at feeding levels of 24 to 35 $\mathrm{mg} / \mathrm{kg}$ (above feeding levels currently approved in the United States)

One study was short-term $(<14 \mathrm{~d})$; the others were long-term (11 and $\sim 29$ wk) Reduced feed intake in bee cattle with improved feed efficiency

Also expensive

May require encapsulation to slow volatilization; see also reviews by Calsamigli et al. (2007) and Benchaar et al. (2008)

Only short-term studies

Potential negative effect on protein nutrition, fiber digestibility, and milk yield; see also review by Waghor (2008)

As electron acceptors, these compounds have to be supplied in stoichiometric proportions, which may make them unrealistic (Weimer, 1998); risk of nitrite toxicity

Only demonstrated in gnotobiotically raised lambs; likely requires elimination of methanogens 
production level, but only $3.1 \%$ decrease at a $13,000-\mathrm{kg}$ production level, assuming no change in digestibility or rumen fermentation.

Although selection for reduced body size is theoretically possible, it has not been widely pursued. The ability to reduce body size while maintaining milk yield is limited due to the amount of feed that can be consumed by smaller animals. Also, a smaller animal contributes less to the beef supply. Currently in the United States, Holstein steers and culled dairy cows of all breeds account for $22 \%$ of domestically produced beef. In Europe, dairy animals account for $50 \%$ of the beef supply (Zehetmeier et al., 2012) and worldwide, meat from dairy breed animals is estimated to be $57 \%$ of the beef supply (FAO, 2010).

Although it is often speculated in the dairy industry that Jersey cows are more energy efficient than Holsteins due to their smaller body sizes and higher content of milk solids, the research literature does not generally support this concept. Research on energy metabolism of mature Jersey and Holstein cows did not show any breed differences for maintenance and production requirements per unit of metabolic $\mathrm{BW}\left(\mathrm{BW}^{0.75}\right.$; Tyrrell et al., 1991). Consequently, $\mathrm{CH}_{4}$ production per unit of milk was not different between the 2 breeds. In a 3-breed comparison with direct measurements of $\mathrm{CH}_{4}$ and milk production, no differences were found between Jerseys and Holsteins in $\mathrm{CH}_{4}$ per DMI or $\mathrm{CH}_{4}$ / ECM (Münger and Kreuzer, 2006). The third breed, Simmental, had similar $\mathrm{CH}_{4}$ per DMI but more $\mathrm{CH}_{4}$ / ECM during lactation as a consequence of the lower milk production as a proportion of body size and correspondingly greater proportion of $\mathrm{CH}_{4}$ associated with maintenance (Münger and Kreuzer, 2006). In contrast, in recent cross-breeding experiments, first-lactation Jersey cows produced more ECM per unit of metabolic BW than Holsteins and Jersey-Holstein first-generation (F1) crosses (Olson et al., 2010). However, it appears that the Jerseys were more physiologically mature at calving than the Holsteins and did not use as much energy in support of growth during the first lactation. Whether this breed difference in energy efficiency would continue into the second-and-greater lactations is unknown and would require further study.

Residual feed intake (RFI) and residual solids production (RSP) are related approaches in which cows are genetically selected for those that are more efficient in using feed nutrients to synthesis milk components at a fixed body size (Herd and Arthur, 2009; Coleman et al., 2010). Dilution of maintenance costs is implicit in both approaches. Residual feed intake follows a normal distribution, which improves its utility for conventional genetic selection compared with feed efficiency (kg of $\mathrm{ECM} / \mathrm{kg}$ of DMI), which is usually not normally dis- 
tributed (St-Pierre and Thraen, 1999). Although the genetic and physiological basis of RFI is sound (Herd and Arthur, 2009), applying RFI to dairy cattle has some concerns because of the high correlation between DMI and BW and the sensitivity of the estimate to the measurement period during lactation (Coleman et al., 2010).

Heritabilities for RFI in dairy cattle have been estimated at 0.01 to 0.40 (Coleman et al., 2010; de Haas et al., 2011; Connor et al., 2012; Basarab et al., 2013). Some of these heritabilities may be overestimated, as they were determined in single herds. Also, the genetic variation in RFI is $<15 \%$ in dairy cattle (Coleman et al., 2010), thus limiting the magnitude of the potential for reductions in enteric $\mathrm{CH}_{4} / \mathrm{ECM}$ to $<5 \%$. Altered digestibility does not appear to be a major contributor to differences in RFI and RSP between cows (Coleman et al., 2010; Waghorn and Hegarty, 2011). An exception was reported by Rius et al. (2012), where a tendency toward increased DM and OM digestibility was observed in first-lactation animals that had been selected for negative RFI as growing heifers, although no difference in DMI existed during the short lactation trial. Using RFI or RSP in a selection index will reduce enteric $\mathrm{CH}_{4} / \mathrm{ECM}$ in direct proportion to the reduction in DMI or increase in milk solids yield (e.g., a $1 \%$ reduction in DMI or $1 \%$ increase in milk solids will reduce $\mathrm{CH}_{4} / \mathrm{ECM}$ by $1 \%$ ), with the assumption that digestibility has not been affected.

Lifetime Production. Last, genetic approaches that improve health, disease resistance, reproduction, and tolerance to heat stress will lead to increases in individual lifetime and herd productivity and indirectly reduce $\mathrm{CH}_{4}$ emissions per unit of milk. Incidences of common diseases in dairy cattle have low to moderate heritabilities $\left(\mathrm{h}^{2}=0.05\right.$ to 0.25 ; Uribe et al., 1995; Zwald et al., 2004) and are positively associated with selection for increased milk production (Rauw et al., 1998). Tolerance to heat stress is also heritable (Ravagnolo and Misztal, 2000). During the past decade, selection indexes for dairy cattle have been modified to include reproductive traits, susceptibility to mastitis, and productive life (lifetime net merit index; VanRaden, 2004), all of which will increase the efficiency of milk production and further reduce $\mathrm{CH}_{4}$ emissions if used by dairy producers. Genetic selection for ECM has been demonstrated to reduce $\mathrm{CH}_{4} / \mathrm{ECM}$ by $15 \%$ for the first 3 lactations until mature size and maximum milk yield are achieved (Bell et al., 2011).

In summary, genetic selection for milk yield, energy efficiency with either RFI or RSP, disease resistance, and heat tolerance will result in reductions in enteric $\mathrm{CH}_{4} / \mathrm{ECM}$ through increased milk yield, dilution of maintenance feed costs, and reduced need for replace-

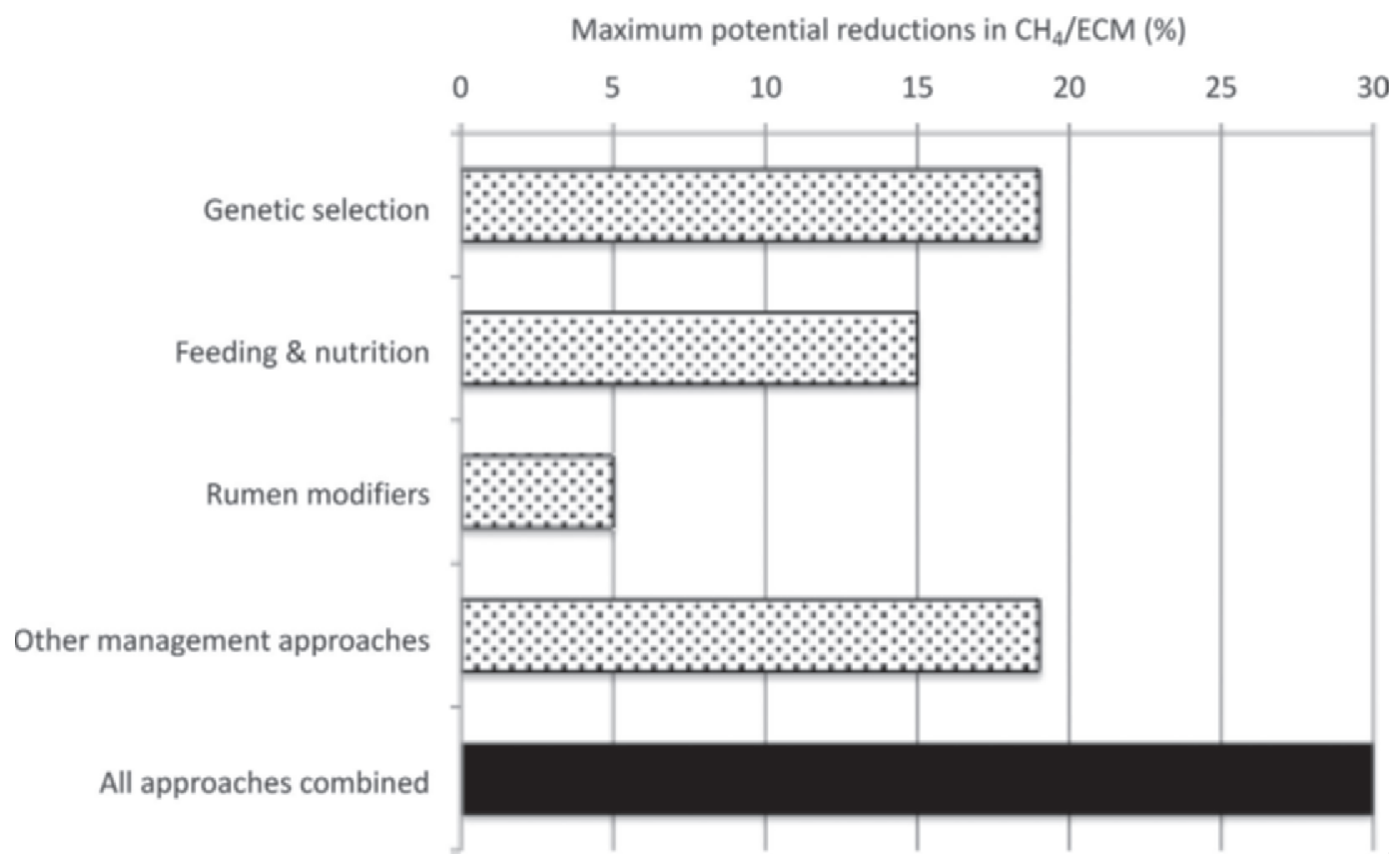

Figure 7. Estimated maximum impact of various approaches to mitigating $\mathrm{CH}_{4}$ in intensive dairy production that have been demonstrated to be effective on an in vivo basis. Approaches are not expected to be fully additive; lower additivity would reduce impacts in each category. Detailed information on the estimates for each category is provided in the respective sections of the text. 
Table 4. Reducing age at first calving and culling frequency reduces the number of replacements needed and enteric $\mathrm{CH}_{4}$ emissions per unit of ECM $\left(\mathrm{CH}_{4} / \mathrm{ECM}\right)$ at the herd level

\begin{tabular}{|c|c|c|c|c|}
\hline \multirow[b]{2}{*}{ Culling rate $(\%)$} & \multicolumn{4}{|c|}{ Age at first calving (mo) } \\
\hline & 22 & 24 & 26 & 28 \\
\hline & \multicolumn{4}{|c|}{ - No. of replacements needed per 100 cows $^{1}$} \\
\hline 25 & 54 & 59 & 64 & 69 \\
\hline 30 & 65 & 71 & 76 & 82 \\
\hline 35 & 75 & 82 & 89 & 96 \\
\hline \multirow[t]{2}{*}{40} & 86 & 94 & 102 & 110 \\
\hline & - Replac & atributi & hole-he & $\mathrm{CH}_{4}^{2}(\%)-$ \\
\hline 25 & 19.6 & 21.0 & 22.4 & 23.7 \\
\hline 30 & 22.7 & 24.2 & 25.7 & 27.2 \\
\hline 35 & 25.5 & 27.2 & 28.8 & 30.3 \\
\hline 40 & 28.1 & 29.9 & 31.6 & 33.2 \\
\hline
\end{tabular}

${ }^{1}$ Calculated from St-Pierre (1998), based on $5 \%$ of heifers born dead on arrival and $10 \%$ culling and mortality. ${ }^{2}$ Calculated based on number of replacement heifers required; lactating cows with mature $\mathrm{BW}=680 \mathrm{~kg}$, producing $31.8 \mathrm{~kg}$ of ECM; DMI calculated according to NRC (2001); and methane production $=5.6 \%$ gross energy intake for lactating cows, $7.0 \%$ for nonlactating mature cows, and $8.0 \%$ for replacement heifers.

ment animals. The biological bases of some of these approaches are redundant, and they would not be expected to fully additive. The combined impact of these genetic approaches in intensive dairy operations on reducing enteric $\mathrm{CH}_{4} / \mathrm{ECM}$ is estimated to be 9 to $19 \%$ (Figure 7), with part of it being manifested at the individual cow level (milk yield; Figure 6) and part through reductions at the herd level (lower culling and fewer replacement animals; Table 4). Although genomic approaches give promise of being able to capitalize on the heritable, between-animal variation in enteric $\mathrm{CH}_{4}$ production $(\mathrm{g} / \mathrm{d})$ as a genetic selection approach, they have not yet been developed to the point of demonstrating actual $\mathrm{CH}_{4} / \mathrm{ECM}$ reductions in dairy cattle. Also, the results of genetic selection are permanent, unlike management approaches, but must be supported by adequate management to achieve the desired reductions in enteric $\mathrm{CH}_{4} / \mathrm{ECM}$.

\section{Management Approaches to Improve Productivity and Reduce $\mathrm{CH}_{4} / \mathrm{ECM}$}

Approximately 50 to $55 \%$ of the increase in milk yields under intensive management has been achieved by genetic selection, and the remainder through improvements in management practices (Hansen, 2000; VanRaden, 2004; Shook, 2006). Animals cannot reach their full genetic potential if factors in their environment are limiting. Currently, a wide range in herd average milk yields exists, which reflects the variation in genetic potential and the variation in environment, which is altered by management practices. Herd production averages in the United Kingdom and United States range from 50 to $150 \%$ of the average, with individual animals recorded at $>350 \%$ of the average
(Wall et al., 2012; R. A. Cady, Elanco Animal Health, Greenfield, IN, personal communication; Holstein Association, 2013).

Management practices that enhance the ability of individual cows to increase milk yields and reach their genetic potential will reduce the amount of $\mathrm{CH}_{4} / \mathrm{ECM}$ in the whole herd. These management approaches may include practices to reduce nonvoluntary culling and diseases, facility and equipment designs to improve the cows' environment, and use of performance-enhancing technologies [e.g., recombinant bST (rbST)] as well as improvements in nutrition and feed delivery. All of these approaches have potential to improve profitability as well as decrease $\mathrm{CH}_{4}$ emissions (Knapp et al., 2011).

Heat Stress Abatement. Animal responses to heat stress include reduced DMI, decreased average daily gain, decreased milk yield, and decreased fertility and poor reproduction (Kadzere et al., 2002; Hansen, 2007). Heat stress also contributes to increased culling and death losses (St-Pierre et al., 2004). During heat stress, milk production is decreased more than DMI, which increases $\mathrm{CH}_{4} / \mathrm{ECM}$ (Rhoads et al., 2009). It may not be the extent of heat stress alone that affects animals, but also the duration of the heat stress (Hubbard et al., 1999; St-Pierre et al., 2004). This is supported by anecdotal evidence from the dairy industry, where it is commonly observed that adequate night cooling reduces the impact of heat stress during multiple-day periods of elevated temperature and humidity.

The minimum threshold where animals begin experiencing heat stress is considered to be a function of production level (Bouraoui et al., 2002; Kadzere et al., 2002; St-Pierre et al., 2004; Zimbelman, 2008). Endogenous heat production increases with the increased DMI and metabolism associated with increased milk yields 
(Kadzere et al., 2002). Ravagnolo and Misztal (2000) found a negative genetic correlation $(\mathrm{r}=-0.36)$ between the heritability for milk yield and heat tolerance. This finding suggests that as dairy cattle have been selected for improved milk yields, their tolerance to heat stress has decreased. A $25 \%$ improvement in heat stress tolerance is estimated to reduce culling by $2.5 \%$, deaths by $0.5 \%$, and milk production losses by 1,000 $\mathrm{kg} /$ cow per year, with a net reduction in $\mathrm{CH}_{4} / \mathrm{ECM}$ of $10 \%$ in intensive dairy systems (St-Pierre et al., 2004; Table 4; Figure 7). An additional consideration with regard to environmental sustainability is that current management approaches for heat stress abatement use large amounts of water to enhance evaporative cooling and require electricity to pump water and run fans. Strategies that reduce or eliminate water and fan use in heat abatement may have substantial economic as well as environmental sustainability value in the future.

Disease in the Transition Period. One of the most challenging areas in dairy cattle management is the transition period from gestation to lactation. The highest incidence of metabolic and infectious diseases is seen in the first $60 \mathrm{~d}$ postcalving, with corresponding high rates of culling, death, and loss of lifetime production (De Vries, 2004; Hadley et al., 2006; Overton and Fetrow, 2008). Across all stages of lactation, culling for disease and lameness accounts for $20 \%$ of all culling (Godden et al., 2003; Hadley et al., 2006). Many of the diseases that occur during the transition period are interrelated, and a cow that experiences one disease is more likely to experience additional diseases (Curtis et al., 1985; Burhans et al., 2003). Also, cows that experience disease early in the lactation are more likely to have poor production and poor reproduction, with increased days open and increased services per conception (Schrick et al., 2001). During the transition period, cows are more sensitive to heat stress, resulting in poor milk production and poor reproduction (De Vries, 2004). Management improvements that decrease the incidence of infectious disease and metabolic disorders during the transition period will decrease involuntary culling and death loss, and increase individual cow productivity. A $5 \%$ reduction in culling for disease during this period, combined with increased milk yields of $1,000 \mathrm{~kg} / \mathrm{cow}$ per year, is estimated to reduce whole-herd emissions by 8 to $12 \%\left(\mathrm{CH}_{4} / \mathrm{ECM}\right.$; Table 4 ; Figure 7$)$.

Production-Enhancing Agents. Ionophores, direct-fed microbes, enzymes, and rbST are available for use in the United States. These products increase feed efficiency, buffer ruminal $\mathrm{pH}$ to prevent acidosis, inhibit unwanted microbes or stimulate beneficial microbes in the rumen, accelerate growth, and increase milk yields. By doing this, production is enhanced and $\mathrm{CH}_{4}$ emissions generally decrease per unit of product.
Recombinant bST reduces maintenance inputs relative to production output, making more efficient use of dietary energy and protein to meet milk production requirements (Bauman, 1992; Baldwin and Knapp, 1993; Capper et al., 2008). Johnson et al. (1992) estimated that increasing productivity by $13 \%$ through use of rbST would result in a $9 \%$ decrease in $\mathrm{CH}_{4}$ emissions in a herd on a per-day or per-year basis. Furthermore, modeling indicates that rbST-treated dairy herds have less whole-farm GHG emissions and an overall reduced impact on the environment, compared with the same production from conventional or organic dairy farms (Capper et al., 2008).

Fertility. Reproduction is obligatory in all domestic livestock species (Flowers, 2013). For dairy cattle, gestation and lactation overlap; cows ideally become pregnant 3 to 4 mo after calving and beginning the current lactation. Although declining fertility in dairy cattle, particularly in North American Holsteins, has been a concern (Hansen, 2000; Lucy, 2001; LeBlanc, 2013), indications are that this trend has been stalled or reversed (USDA, 2012). Reproductive efficiency affects dairy farm profitability (De Vries, 2006) because cows in well-managed reproduction programs spend more time in the highest-yielding part of their lactations and have longer productive lifetimes. Also, fewer replacement animals are needed in herds with better reproduction rates (Table 4).

Approximately 19\% of culling decisions are for reproductive reasons (Hadley et al., 2006). A reduction in culling due to poor reproduction from 35 to $30 \%$ is estimated to reduce whole-herd enteric $\mathrm{CH}_{4}$ emissions by $3.1 \%$ when age at first calving is 26 mo. This estimate does not include the improvement in lifetime productivity that accompanies improvements in reproduction. Additionally, dairy profitability is improved by reducing days open that are beyond the optimum (Groenendaal et al., 2004; De Vries, 2006). The economic value of reduced days open is not only a function of the mean days open but also of its variance.

\section{Reducing the Number of Dry Cows and Replacement Heifers}

Reduced culling reduces the requirement for replacement animals and is an immediately effective approach to reduce $\mathrm{CH}_{4} / \mathrm{ECM}$ and increase dairy profitability. The improvements in genetic selection and management discussed above and in Knapp et al. (2011) can further augment efforts to reduce $\mathrm{CH}_{4} / \mathrm{ECM}$ on a herd basis. The number of dry cows in a herd is largely a reflection of the effectiveness of the reproduction program used. Good reproduction management will result in an optimal dry period length for individual cows 
that is a balance between having a minimum dry period that allows mammary tissue to involute and regenerate to achieve good production in the following lactation versus having too long a period with no production. Effective reproduction programs will also effectively increase milk per cow by having cows spend more of their productive days in the higher-producing periods of the lactation production cycle (De Vries, 2006; Wall et al., 2012). Similarly, extended lactations are not predicted to reduce $\mathrm{CH}_{4} / \mathrm{ECM}$ because of lower milk yields in late lactation (Wall et al., 2012).

With replacement heifers, the number needed is a function of culling of the older cows in the lactating herd, age at first calving, heifer mortality and culling, and farm goals for expansion (Table 4). Reducing the age at first calving for properly developed heifers will reduce the energy requirements during the growing period, which is a non-milk productive period that contributes substantially to the maintenance energy required by the herd. Decreasing mortality and morbidity rates also has a significant effect on $\mathrm{CH}_{4}$ reduction because animals that die or are culled before their first lactation represent a significant use of energy and resources without any usable food being produced. Lower culling levels, reduced age at first calving, and reduced heifer mortality would reduce the number of replacement heifers needed, and this would be accompanied by a corresponding, but smaller, decrease in $\mathrm{CH}_{4}$ emissions by the whole herd (Table 4; Figure 7). These estimates are in accordance with estimates for United Kingdom herds, where the replacement stock accounted for 21 to $26 \%$ of whole-herd enteric $\mathrm{CH}_{4}$ emissions (Wall et al., 2012). For example, reducing culling from 35 to $30 \%$ and age at first calving from 26 to 24 mo at the same herd average milk yield would decrease enteric $\mathrm{CH}_{4}$ contributed by the replacement animals to whole-herd emissions by $4.6 \%$ (Table 4 ).

However, culling levels that are too low compromise genetic progress from generation to generation, and heifers calving too young $(<21 \mathrm{mo})$ result in lower lifetime production (Gill and Allaire, 1976). Reducing heifer mortality and culling results in an equal reduction in the proportion of heifers needed as replacements (i.e., a 5\% reduction in heifer mortality and culling translates into $5 \%$ less heifers needed) and provides a substantial opportunity for the dairy industry to reduce $\mathrm{CH}_{4}$ emissions while improving animal welfare (Figure 7). However, reducing culling of heifers and mature cows will decrease the amount of beef contributed by the dairy industry and would require an increase in beef animals to maintain the same national or global supply. Also, beef from dairy animals produces significantly less GHG per kilogram of meat than meat produced either in feedlot or extensive production systems, due

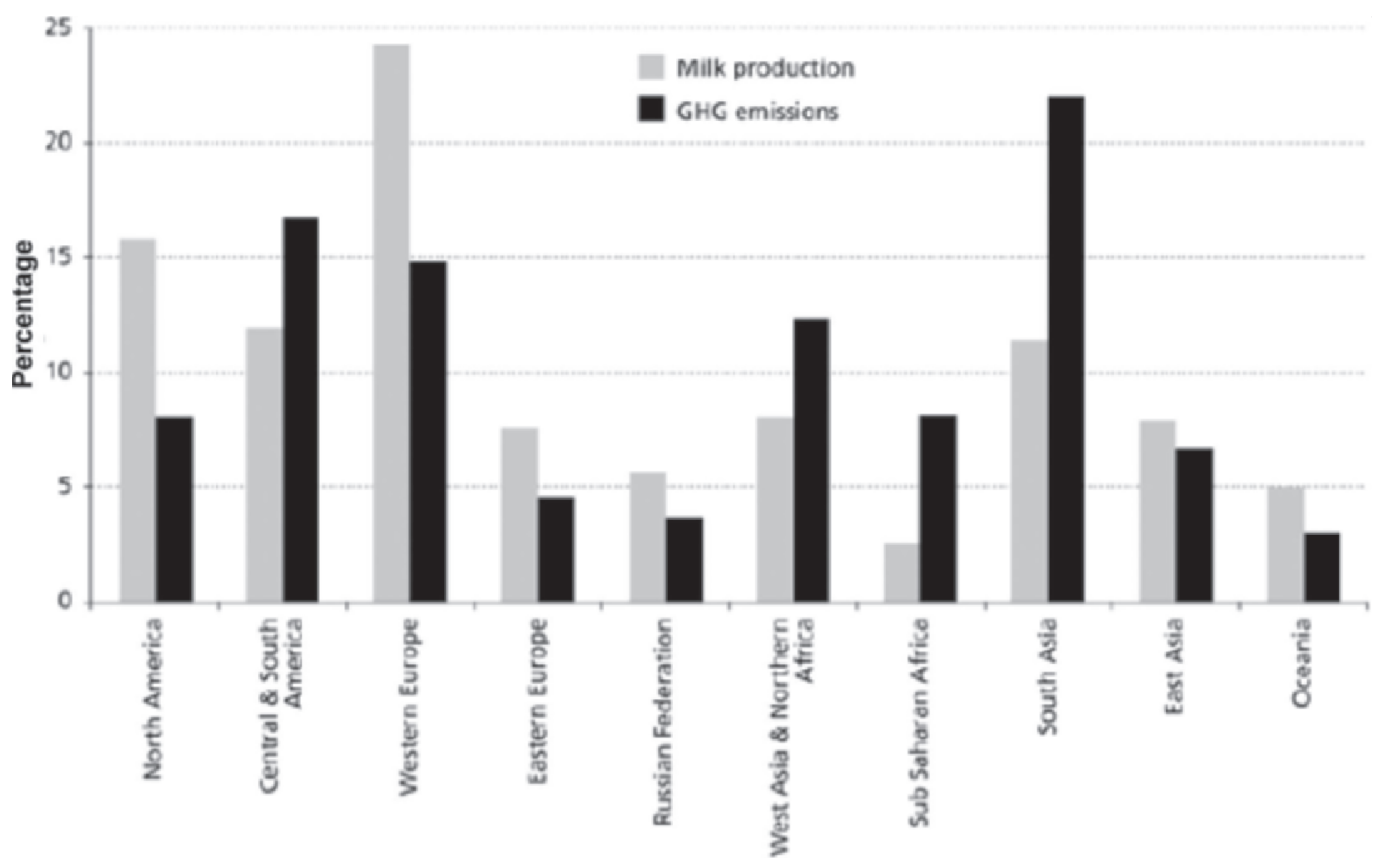

Figure 8. Intensive dairy production in developed countries contributes less greenhouse gas (GHG) emissions per unit of ECM than extensive systems in developing countries. Emissions and production for each region given as percentage of global total. Global milk production was 553 million tonnes, meat from dairy animals was 37 million tonnes, and GHG emissions associated with dairy production (milk and meat) were 1,969 million tonnes of $\mathrm{CO}_{2}$ equivalents $\left[\mathrm{CO}_{2} \mathrm{e}\right.$; 2007 estimates; from FAO (2010); reprinted with permission from the Food and Agriculture Organization of the United Nations (FAO)]. 
to the dual-product nature of dairying ( $<10$ vs. 15 to $70 \mathrm{~kg}$ of $\mathrm{CO}_{2} \mathrm{e} / \mathrm{kg}$ of meat; FAO, 2010; Zehetmeier et al., 2012; Gerber et al., 2013).

In summary, management approaches other than nutrition and feeding, including heat stress abatement, disease control and treatment, performance enhancing technologies, and reproductive management can increase milk yields and reduce culling and the need for replacement animals. Several of these approaches are additive, although they may not be fully so. These improvements in animal and herd performance are estimated to lower enteric $\mathrm{CH}_{4} / \mathrm{ECM}$ by 9 to $19 \%$, depending on the genetic potential of the cows (Figure 7).

\section{Potential for Reducing $\mathrm{CH}_{4}$ Emissions from Dairy Production Around the World}

On a global basis, GHG emissions estimated in lifecycle assessments of dairy production vary by country from 1 to $7.5 \mathrm{~kg}$ of $\mathrm{CO}_{2} \mathrm{e} / \mathrm{kg}$ of ECM, with an average of $2.4 \pm 0.6 \mathrm{~kg}$ of $\mathrm{CO}_{2} \mathrm{e} / \mathrm{kg}$ of ECM (FAO, 2010; Hagemann et al., 2011), of which only a part is enteric $\mathrm{CH}_{4}$. Of the GHG emissions, $67 \%$ was attributed to milk and $33 \%$ to meat (FAO, 2010). The estimate of GHG per kilogram of meat is very sensitive to the allocation basis (product mass vs. protein content vs. economic value), whereas GHG/ECM is less so (FAO, 2010; Hagemann et al., 2011; Mc Geough et al., 2012; Zehetmeier et al., 2012). Meat from dairy animals was estimated to contribute $57 \%$ of the global beef production and $13 \%$ of global livestock and poultry meat production (FAO, 2010). Intensively managed dairy production systems in developed countries contribute the least $\mathrm{CO}_{2} \mathrm{e} / \mathrm{ECM}$, whereas extensive production systems in developing countries have the highest (Figure 8; FAO, 2010; Hagemann et al., 2011). Globally, on-farm emissions were estimated to be $93 \%$ of total GHG emissions in dairy production, and included $\mathrm{CO}_{2}$ from fuel and electricity usage, $\mathrm{CH}_{4}$ from enteric and manure fermentation, and $\mathrm{N}_{2} \mathrm{O}$ from crop fertilization and manure (FAO, 2010). However, enteric $\mathrm{CH}_{4}$ and on-farm GHG emissions from dairy production contribute only approximately 25 and $70 \%$, respectively, in developed countries where more emissions associated with off-farm feed production and postharvest processing and consumption occur (Gill et al., 2010; Thoma et al., 2013).

The conservative estimates in this analysis suggest that reductions of 15 to $30 \%$ in enteric $\mathrm{CH}_{4} / \mathrm{ECM}$ can be achieved in intensive dairy operations using combinations of several strategies (Figure 7). These estimates are somewhat less than estimates in the analysis by Gerber et al. (2013), likely due to an emphasis on systems that currently attain high levels of animal productivity and the recognition that few of the approaches will be fully additive. Most of these approaches are not novel, but they are proven. They are the results of decades of research in genetics, microbiology, nutrition, physiology, and veterinary medicine from scientists around the world. Also, they underlay the 5-fold difference in GHG/ ECM emissions between intensive operations, including confinement housing and intensively managed grazing dairies, and extensive dairy operations. The upper end of the estimated reductions in this analysis, largely based on confinement housing, is not significantly different than the estimate of 27 to $32 \%$ improvement in GHG per hectare for managed grazing where milk yield per hectare was held constant (Beukes et al., 2010), reinforcing the idea that concepts underlying $\mathrm{CH}_{4}$ mitigation via improvements in production efficiency have been and can be applied to different management systems as appropriate (Waghorn, 2011). To continue achieving gains in animal productivity requires a shift from focusing solely on milk or milk component yields to adding an emphasis on traits to enhance lifetime productivity and feed efficiency. This emerging paradigm is being implemented in genetics by the addition of traits for lifetime productivity and residual feed intake in selection indexes in several countries. Cattle management, including nutrition, reproduction, health, and facility design will need to continue improving to support the genetic progress.

Significantly more opportunity exists in extensive systems to reduce $\mathrm{CH}_{4} / \mathrm{ECM}$ through combinations of genetic selection, forage production, nutrition, and other management approaches (FAO, 2010; Gerber et al., 2013). The scientific basis for these improvements already exists; achieving them depends on economics, government policy, and cultural considerations (Gerber et al., 2013). The approaches discussed in this review can be implemented in any country or region and will benefit dairy production. A more detailed discussion of regional GHG mitigation opportunities can be found in Gerber et al. (2013).

Several countries, especially New Zealand, Australia, Canada, and the Netherlands, have invested heavily in $\mathrm{CH}_{4}$ abatement research in livestock through their agricultural research institutions, and private industry is also contributing. Since 2002, New Zealand has made a concerted effort to identify $\mathrm{CH}_{4}$ mitigation strategies through the formation of the Pastoral Greenhouse Gas Research Consortium (PGgRc; http://www. pggrc.co.nz). Several international scientific organizations have been established to further collaboration and capitalize on synergies between research groups, including the Global Research Alliance (http://www. globalresearchalliance.org) and Livestock Emissions and Abatement Research Network (LEARN; http:// www.livestockemissions.net). Achieving substantial im- 
provements in dairy cattle productivity and reductions in emissions of $\mathrm{CH}_{4} / \mathrm{ECM}$ basis requires the collaboration of scientists from multiple disciplines, including agronomy and soil science, economics, engineering, genetics, nutrition, reproductive physiology, and veterinary medicine.

\section{CONCLUSIONS}

Research in genetics, health, microbiology, nutrition, and physiology and application of the results to dairy production have led to tremendous improvements in animal performance over the past century. These improvements provide a growing supply of milk that minimizes the environmental impact of GHG emissions from dairy cattle. Continued application of these approaches to dairy production as well as research and development of novel methods can further reduce enteric $\mathrm{CH}_{4}$ and other GHG per unit of product while increasing the milk supply needed to meet the anticipated $58 \%$ increase in global dairy demand by 2050 (FAO, 2011).

Genetic selection for feed efficiency, heat tolerance, disease resistance, and fertility can augment selection for milk yield in reducing enteric $\mathrm{CH}_{4} / \mathrm{ECM}$ with the potential of 9 to 19\% reductions (Figure 7). To achieve enteric $\mathrm{CH}_{4} / \mathrm{ECM}$ reductions through genetic selection requires appropriate supporting management, including feeding and nutrition, health, reproduction, and housing facility design. Feeding and nutrition have modest ( 2.5 to $15 \%$ ) potential to mitigate enteric $\mathrm{CH}_{4} / \mathrm{ECM}$ in intensive dairy operations in developed countries, with significantly more potential when combined with crop and forage production in developing countries (Figure 7; FAO, 2010; Gerber et al., 2013). Impacts of feeding and nutrition will be mostly achieved by approaches that improve feed efficiency. Feed additives, chemical inhibitors, and biological approaches to altering methanogen populations, activities, and rumen fermentation cannot compromise rumen digestibility and fermentation if they are to be viable $\mathrm{CH}_{4}$-reduction approaches. To date, rumen modifiers other than nitrates have not shown sustained reductions in $\mathrm{CH}_{4} / \mathrm{ECM}$. Feeding approaches and rumen modifiers that shift digestion to the hindgut or to manure in storage will not result in net reductions in $\mathrm{CH}_{4}$ emissions at the farm level. Improvements in estrus detection, estrus synchronization, prevention of early embryonic death, heat stress abatement, and transition cow health would result in improvements in reproduction, reduce the number of cows culled due to poor reproduction and disease, and reduce the number of replacement animals needed. These management approaches could reduce enteric $\mathrm{CH}_{4} / \mathrm{ECM}$ by 9 to $19 \%$ (Figure 7 ).
Recognizing that genetic and management mitigation approaches presented in this review will not be fully additive and some cannot be applied to the whole herd in a dairy operation, we estimate that their combined potential to reduce enteric $\mathrm{CH}_{4} / \mathrm{ECM}$ is 15 to $30 \%$ in intensively managed dairy production systems that are already achieving high animal performance. Implementation of any strategy to mitigate enteric $\mathrm{CH}_{4}$ must consider the impact on other GHG emissions from the dairy production unit and the impact on other agricultural sectors, especially beef production. Adoption of mitigation strategies by dairy producers will depend on these considerations as well as the feasibility of implementation, economic impact, and regulatory policy.

\section{ACKNOWLEDGMENTS}

We thank Jeffrey Firkins (The Ohio State University, Columbus) for reviewing this manuscript, our colleagues who coauthored and reviewed the Cow of the Future white paper, and the Innovation Center for US Dairy (Rosemont, IL) for partial funding of this project.

\section{REFERENCES}

Aguerre, M. J., M. A. Wattiaux, J. M. Powell, G. A. Broderick, and C. Arndt. 2011. Effect of forage-to-concentrate ratio in dairy cow diets on emission of methane, carbon dioxide, and ammonia, lactation performance, and manure excretion. J. Dairy Sci. 94:30813093.

Allen, M. S. 2000. Effects of diet on short-term regulation of feed intake by lactating dairy cattle. J. Dairy Sci. 83:1598-1624.

Anderson, R. C., G. E. Carstens, R. K. Miller, T. R. Callaway, C. L. Schultz, T. S. Edrington, R. B. Harvey, and D. J. Nisbet. 2004. Effect of nitroethane administration on ruminal VFA production and specific activity of methane production. J. Anim. Feed Sci. 13(Suppl. 1):23-26.

Anderson, R. C., G. E. Carstens, R. K. Miller, T. R. Callaway, C. L. Schultz, T. S. Edrington, R. B. Harvey, and D. J. Nisbet. 2006. Effect of oral nitroethane and 2-nitropropanol administration on methane-producing activity and volatile fatty acid production in the ovine rumen. Bioresour. Technol. 97:2421-2426.

Anderson, R. C., N. A. Krueger, T. B. Stanton, T. R. Callaway, T. S. Edrington, R. B. Harvey, Y. S. Jung, and D. J. Nisbet. 2008. Effects of select nitrocompounds on in vitro ruminal fermentation during conditions of limiting or excess added reductant. Bioresour. Technol. 99:8655-8661.

Andrew, S. M., H. R. Tyrrell, C. K. Reynolds, and R. A. Erdman. 1991. Net energy for lactation of calcium salts of long-chain fatty acids for cows fed silage-based diets. J. Dairy Sci. 74:2588-2600.

Animut, G., R. Puchala, A. L. Goetsch, A. K. Patra, T. Sahlu, V. H. Varel, and J. Wells. 2008. Methane emission by goats consuming diets with different levels of condensed tannins from lespedeza. Anim. Feed Sci. Technol. 144:212-227.

Archimède, H., M. Eugène, C. Marie Magdeleine, M. Boval, C. Martin, D. P. Morgavi, P. Lecomte, and M. Doreau. 2011. Comparison of methane production between C3 and C4 grasses and legumes. Anim. Feed Sci. Technol. 166-167:59-64.

Baldwin, R. L., and M. J. Allison. 1983. Rumen metabolism. J. Anim. Sci. 57 (Suppl. 2):461-477. 
Baldwin, R. L., and J. R. Knapp. 1993. Recombinant bovine somatotropin's effects on patterns of nutrient utilization in lactating dairy cows. Am. J. Clin. Nutr. 58:282S-286S.

Bannink, A., J. Kogut, J. Dijkstra, J. France, E. Kebreab, A. M. Van Vuuren, and S. Tamminga. 2006. Estimation of the stoichiometry of volatile fatty acid production in the rumen of lactating cows. J. Theor. Biol. 238:36-51.

Basarab, J. A., K. A. Beauchemin, V. S. Baron, K. H. Ominski, L. L. Guan, S. P. Miller, and J. J. Crowley. 2013. Reducing GHG emissions through genetic improvement for feed efficiency: Effects on economically important traits and enteric methane production. Animal 7:303-315.

Bauman, D. E. 1992. Bovine somatotropin: Review of an emerging animal technology. J. Dairy Sci. 75:3432-3451.

Beauchemin, K., and S. McGinn. 2006a. Enteric methane emissions from growing beef cattle as affected by diet and level of intake. Can. J. Anim. Sci. 86:401-408.

Beauchemin, K. A., M. Kreuzer, F. O'Mara, and T. A. McAllister 2008. Nutritional management for enteric methane abatement: A review. Aust. J. Exp. Agric. 48:21-27.

Beauchemin, K. A., and S. M. McGinn. 2006b. Methane emissions from beef cattle: Effects of fumaric acid, essential oil, and canola oil. J. Anim. Sci. 84:1489-1496.

Beauchemin, K. A., S. M. McGinn, C. Benchaar, and L. Holtshausen. 2009. Crushed sunflower, flax, or canola seeds in lactating dairy cow diets: Effects on methane production, rumen fermentation, and milk production. J. Dairy Sci. 92:2118-2127.

Beauchemin, K. A., S. M. McGinn, T. F. Martinez, and T. A. McAllister. 2007a. Use of condensed tannin extract from quebracho trees to reduce methane emissions from cattle. J. Anim. Sci. 85:19901996.

Beauchemin, K. A., S. M. McGinn, and H. V. Petit. 2007b. Methane abatement strategies for cattle: Lipid supplementation of diets. Can. J. Anim. Sci. 87:431-440.

Bell, M. J., E. Wall, G. Simm, and G. Russell. 2011. Effects of genetic line and feeding system on methane emissions from dairy systems. Anim. Feed Sci. Technol. 166-167:699-707.

Benchaar, C., S. Calsamiglia, A. V. Chaves, G. R. Fraser, D. Colombatto, T. A. McAllister, and K. A. Beauchemin. 2008. A review of plant-derived essential oils in ruminant nutrition and production. Anim. Feed Sci. Technol. 145:209-228.

Benchaar, C., F. Hassanat, R. Gervais, P. Y. Chouinard, C. Julien, H. V. Petit, and D. I. Massé. 2013. Effects of increasing amounts of corn dried distillers grains with solubles in dairy cow diets on methane production, ruminal fermentation, digestion, $\mathrm{N}$ balance, and milk production. J. Dairy Sci. 96:2413-2427.

Beukes, P. C., P. Gregorini, A. J. Romera, G. Levy, and G. C. Waghorn. 2010. Improving production efficiency as a strategy to mitigate greenhouse gas emissions on pastoral dairy farms in New Zealand. Agric. Ecosyst. Environ. 136:358-365.

Blaxter, K. L., and J. L. Clapperton. 1965. Prediction of the amount of methane produced by ruminants. Br. J. Nutr. 19:511-522.

Boadi, D., C. Benchaar, J. Chiquette, and D. Masse. 2004. Mitigation strategies to reduce enteric methane emissions from dairy cows: Update review. Can. J. Anim. Sci. 84:319-335.

Boadi, D., K. M. Wittenberg, and W. P. McCaughey. 2002. Effects of grain supplementation on methane production of grazing steers using the sulphur $\left(\mathrm{SF}_{6}\right)$ tracer gas technique. Can. J. Anim. Sci. 82:151-157.

Boadi, D. A., and K. M. Wittenberg. 2002. Methane production from dairy and beef heifers fed forages differing in nutrient density using the sulphur hexafluoride $\left(\mathrm{SF}_{6}\right)$ tracer gas technique. Can. J. Anim. Sci. 82:201-206.

Bouraoui, R., M. Lahmar, A. Majdoub, M. Djemali, and R. Belyea. 2002. The relationship of temperature-humidity index with milk production of dairy cows in a Mediterranean climate. Anim. Res. 41:479-491.

Brown, E. G., R. C. Anderson, G. E. Carstens, H. Gutierrez-Bañuelos, J. L. McReynolds, L. J. Slay, T. R. Callaway, and D. J. Nisbet. 2011. Effects of oral nitroethane administration on enteric meth- ane emissions and ruminal fermentation in cattle. Anim. Feed Sci Technol. 166-167:275-281.

Burhans, W. S., A. W. Bell, R. Nadeau, and J. R. Knapp. 2003. Factors associated with transition cow ketosis incidence in selected New England herds. J. Dairy Sci. 86(Suppl. 1):247. (Abstr.)

Callaway, T. R., T. S. Edrington, J. L. Rychlik, K. J. Genovese, T. L. Poole, Y. S. Jung, K. M. Bischoff, R. C. Anderson, and D. J. Nisbet. 2003. Ionophores: Their use as ruminant growth promotants and impact on food safety. Curr. Issues Intest. Microbiol. 4:43-51.

Calsamiglia, S., M. Busquet, P. W. Cardozo, L. Castillejos, and A. Ferret. 2007. Invited review: Essential oils as modifiers of rumen microbial fermentation. J. Dairy Sci. 90:2580-2595.

Capper, J. L., R. A. Cady, and D. E. Bauman. 2009. The environmental impact of dairy production: 1944 compared with 2007. J. Anim. Sci. 87:2160-2167.

Capper, J. L., E. Castañeda-Gutiérrez, R. A. Cady, and D. E. Bauman. 2008. The environmental impact of recombinant bovine somatotropin (rbST) use in dairy production. Proc. Natl. Acad. Sci. USA 105:9668-9673.

Carulla, J. E., M. Kreuzer, A. Machmüller, and H. D. Hess. 2005. Supplementation of Acacia mearnsii tannins decreases methanogenesis and urinary nitrogen in forage-fed sheep. Aust. J. Agric. Res. 56:961-970.

Chagunda, M. G. G., D. A. M. Römer, and D. J. Roberts. 2009. Effect of genotype and feeding regime on enteric methane, non-milk nitrogen and performance of dairy cows during the winter feeding period. Livest. Sci. 122:323-332.

Chilliard, Y. 1993. Dietary fat and adipose tissue metabolism in ruminants, pigs, and rodents: A review. J. Dairy Sci. 76:3897-3931.

Chung, Y.-H., N. D. Walker, S. M. McGinn, and K. A. Beauchemin. 2011. Differing effects of 2 active dried yeast (Saccharomyces cerevisiae) strains on ruminal acidosis and methane production in nonlactating dairy cows. J. Dairy Sci. 94:2431-2439.

Clark, H. 2013. Nutritional and host effects on methanogenesis in the grazing ruminant. Animal 7(Suppl. 1):41-48.

Climate Change Central. 2012. Climate Change Central, Alberta, Canada. Accessed Apr. 1, 2014. http://environment.gov.ab.ca/ info/library/8255.pdf.

Cole, J. B., and P. M. VanRaden. 2011. Use of haplotypes to estimate Mendelian sampling effects and selection limits. J. Anim. Breed. Genet. 128:446-455.

Coleman, J., D. P. Berry, K. M. Pierce, A. Brennan, and B. Horan. 2010. Dry matter intake and feed efficiency profiles of 3 genotypes of Holstein-Friesian within pasture-based systems of milk production. J. Dairy Sci. 93:4318-4331.

Connor, E. E., J. L. Hutchison, K. M. Olson, and H. D. Norman. 2012 Triennial Lactation Symposium: Opportunities for improving milk production efficiency in dairy cattle. J. Anim. Sci. 90:1687-1694.

Curtis, C. R., H. N. Erb, C. H. Sniffen, R. D. Smith, and D. S. Kronfeld. 1985. Path analysis of dry period nutrition, postpartum metabolic and reproductive disorders, and mastitis in Holstein cows. J. Dairy Sci. 68:2347-2360

Czerkawski, J. W. 1986. An Introduction to Rumen Studies. Pergamon Press, Oxford, UK.

Czerkawski, J. W., and G. Breckenridge. 1972. Fermentation of various glycolytic intermediates and other compounds by rumen microorganisms, with particular reference to methane production. $\mathrm{Br}$ J. Nutr. 27:131-146.

de Haas, Y., J. J. Windig, M. P. L. Calus, J. Dijkstra, M. de Haan, A. Bannink, and R. F. Veerkamp. 2011. Genetic parameters for predicted methane production and potential for reducing enteric emissions through genomic selection. J. Dairy Sci. 94:6122-6134.

de Oliveira, S. G., T. T. Berchielli, M. dos Santos Pedreira, O. Primavesi, R. Frighetto, and M. A. Lima. 2007. Effect of tannin levels in sorghum silage and concentrate supplementation on apparent digestibility and methane emission in beef cattle. Anim. Feed Sci Technol. 135:236-248.

De Vries, A. 2004. Economics of delayed replacement when cow performance is seasonal. J. Dairy Sci. 87:2947-2958. 
De Vries, A. 2006. Economic value of pregnancy in dairy cattle. J. Dairy Sci. 89:3876-3885.

Dohme, F., A. Machmüller, F. Sutter, and M. Kreuzer. 2004. Digestive and metabolic utilization of lauric, myristic and stearic acid in cows, and associated effects on milk fat quality. Arch. Anim. Nutr. 58:99-116.

Dohme, F., A. Machmüller, A. Wasserfallen, and M. Kreuzer. 2001. Ruminal methanogenesis as influenced by individual fatty acids supplemented to complete ruminant diets. Lett. Appl. Microbiol. $32: 47-51$

Dohme, F., A. Machmüller, A. Wasserfallen, and W. Kreuzer. 2000. Comparative efficiency of various fats rich in medium-chain fatty acids to suppress ruminal methanogenesis as measured with RUSITEC. Can. J. Anim. Sci. 80:473-482.

Dong, Y., H. D. Bae, T. A. McAllister, G. W. Mathison, and K.-J. Cheng. 1997. Lipid-induced depression of methane production and digestibility in the artificial rumen system (RUSITEC). Can. J. Anim. Sci. 77:269-278.

Dong, Y., H. D. Bae, T. A. McAllister, G. W. Mathison, and K.J. Cheng. 1999. Effects of exogenous fibrolytic enzymes, $\alpha$-bromoethanesulfonate and monensin on fermentation in a rumen simulation (RUSITEC) system. Can. J. Anim. Sci. 79:491-498.

Dumitru, R., H. Palencia, S. D. Schroeder, B. A. DeMontigny, J. M. Takacs, M. E. Rasche, J. L. Miner, and S. W. Ragsdale. 2003. Targeting methanopterin biosynthesis to inhibit methanogenesis. Appl. Environ. Microbiol. 69:7236-7241.

Ecofys. 2013. World GHG emissions flow chart 2010. Accessed Oct. 31 , 2013. http://www.ecofys.com/files/files/asn-ecofys-2013-worldghg-emissions-flow-chart-2010.pdf.

EEA (European Environment Agency). 2011. Annual European Union greenhouse gas inventory 1990-2009 and inventory report 2011. European Environment Agency Technical report No. 2/2011. EEA, Copenhagen, Denmark.

EPA (Environmental Protection Agency). 2005. Opportunities to Reduce Anthropogenic Methane Emissions in the United States. Publication 430-R-93-012. EPA, Washington, DC.

EPA (Environmental Protection Agency). 2006. Global Mitigation of Non- $\mathrm{CO}_{2}$ Greenhouse Gases. Publication 430-R-06-005. EPA, Washington, DC.

EPA (Environmental Protection Agency). 2010. Methane and Nitrous Oxide Emissions from Natural Sources. Publication 430-R-10-001. EPA, Washington, DC.

EPA (Environmental Protection Agency). 2011a. DRAFT: Global Anthropogenic Non- $\mathrm{CO}_{2}$ Greenhouse Gas Emissions: 1990-2030. Publication 430-D-11-003. EPA, Washington, DC.

EPA (Environmental Protection Agency). 2011b. Inventory of U. S. Greenhouse Gas Emissions and Sinks: 1990-2009. Publication 430R-11-005. EPA, Washington, DC.

Eugene, M., D. Masse, J. Chiquette, and C. Benchaar. 2008. Metaanalysis on the effects of lipid supplementation on methane production in lactating dairy cows. Can. J. Anim. Sci. 88:331-334.

FAO (Food and Agriculture Organization of the United Nations). 2010. Greenhouse Gas Emissions from the Dairy Sector: A Life Cycle Assessment. Prepared by P. Gerber, T. Vellinga, C. Opio, B. Henderson, and H. Steinfeld. FAO, Rome, Italy.

FAO (Food and Agriculture Organization of the United Nations). 2011. World Livestock 2011: Livestock in food security. FAO, Rome, Italy.

FAOSTAT. 2014. Time series and cross sectional data relating to food and agriculture for some 200 countries. Accessed Feb. 21, 2014. http://faostat.fao.org/site/291/default.aspx.

Firkins, J. L., M. L. Eastridge, N. R. St-Pierre, and S. M. Noftsger. 2001. Effects of grain variability and processing on starch utilization by lactating dairy cattle. J. Anim. Sci. 79(E. Suppl.):E218E238.

Flowers, W. L. 2013. Animal Frontiers fertility issue: Sex education that everyone needs to understand. Anim. Front. 3:4-5.

Foley, P. A., D. A. Kenny, D. K. Lovett, J. J. Callan, T. M. Boland, and F. P. O'Mara. 2009. Effect of DL-malic acid supplementation on feed intake, methane emissions, and performance of lactating dairy cows at pasture. J. Dairy Sci. 92:3258-3264.
Fonty, G., K. Joblin, M. Chavarot, R. Roux, G. Naylor, and F. Michallon. 2007. Establishment and development of ruminal hydrogenotrophs in methanogen-free lambs. Appl. Environ. Microbiol. 73:6391-6403.

Frumholtz, P. P., C. J. Newbold, and R. J. Wallace. 1989. Influence of Aspergillus oryzae fermentation extract on the fermentation of a basal ration in the rumen simulation technique (Rusitec). J. Agric. Sci. 113:169-172.

Gerber, P. J., H. Steinfeld, B. Henderson, A. Mottet, C. Opio, J. Dijkman, A. Falcucci, and G. Tempio. 2013. Tackling Climate Change through Livestock: A Global Assessment of Emissions and Mitigation Opportunities. Food and Agriculture Organization of the United Nations (FAO), Rome, Italy.

Giger-Reverdin, S., P. Morand-Fehr, and G. Tran. 2003. Literature survey of the influence of dietary fat composition on methane production in dairy cattle. Livest. Prod. Sci. 82:73-79.

Gill, G. S., and F. R. Allaire. 1976. Relationship of age at first calving, days open, days dry, and herdlife to a profit function for dairy cattle. J. Dairy Sci. 59:1131-1139.

Gill, M., P. Smith, and J. M. Wilkinson. 2010. Mitigating climate change: the role of domestic livestock. Animal 4:323-333.

Giraldo, L. A., M. J. Ranilla, M. L. Tejido, and M. D. Carro. 2007a. Influence of exogenous fibrolytic enzymes and fumarate on methane production, microbial growth, and fermentation in Rusitec fermenters. Br. J. Nutr. 98:753-761.

Giraldo, L. A., M. J. Ranilla, M. L. Tejido, and M. D. Carro. 2007b. Effects of exogenous cellulase supplementation on microbial growth and ruminal fermentation of a high-forage diet in Rusitec fermenters. J. Anim. Sci. 85:1962-1970.

Godden, S. M., S. C. Stewart, J. F. Fetrow, P. Rapnicki, R. Cady, W. Weiland, H. Spencer, and S. W. Eicker. 2003. The relationship between herd rbST-supplementation and other factors and risk for removal for cows in Minnesota Holstein dairy herds. Pages 55-64 in Proc. Four-State Nutr. Conf. La Crosse, WI. MidWest Plan Service publication MWPS-4SD16. MidWest Plan Service, Ames, IA.

Golub, A. A. B. B. Henderson, T. W. Hertel, P. J. Gerber, S. K. Rose, and B. Sohngen. 2013. Global climate policy impacts on livestock, land use, livelihoods, and food security. Proc. Natl Acad. Sci. USA 110:20894-20899. http://dx.doi.org/10.1073/ pnas. 1108772109 .

Grainger, C., M. J. Auldist, T. Clarke, K. A. Beauchemin, S. M. McGinn, M. C. Hannah, R. J. Eckard, and L. B. Lowes. 2008a. Use of monensin controlled-release capsules to reduce methane emissions and improve milk production of dairy cows offered pasture supplemented with grain. J. Dairy Sci. 91:1159-1165.

Grainger, C., T. Clarke, M. J. Auldist, K. Beauchemin, S. McGinn, G. C. Waghorn, and R. J. Eckard. 2009. Potential use of Acacia mearnsii condensed tannins to reduce methane emissions and nitrogen excretion from grazing dairy cows. Can. J. Anim. Sci. 89:241-251.

Grainger, C., T. Clarke, K. A. Beauchemin, S. M. McGinn, and R. J. Eckard. 2008b. Supplementation with whole cottonseed reduces methane emissions and can profitably increase milk production of dairy cows offered a forage and cereal grain diet. Aust. J. Exp. Agric. 48:73-76.

Grainger, C., R. Williams, T. Clarke, A.-D. G. Wright, and R. J. Eckard. 2010. Supplementation with whole cottonseed causes longterm reduction of methane emissions from lactating dairy cows offered a forage and cereal grain diet. J. Dairy Sci. 93:2612-2619.

Groenendaal, H., D. T. Galligan, and H. A. Mulder. 2004. An economic spreadsheet model to determine optimal breeding and replacement decisions for dairy cattle. J. Dairy Sci. 87:2146-2157.

Guan, H., K. M. Wittenberg, K. H. Ominski, and D. O. Krause. 2006. Efficacy of ionophores in cattle diets for mitigation of enteric methane. J. Anim. Sci. 84:1896-1906.

Gutierrez-Bañuelos, H., R. C. Anderson, G. E. Carstens, L. J. Slay, N. Ramlachan, S. M. Horrocks, T. R. Callaway, T. S. Edrington, and D. J. Nisbet. 2007. Zoonotic bacterial populations, gut fermentation characteristics and methane production in feedlot steers during oral nitroethane treatment and after the feeding of an experimental chlorate product. Anaerobe 13:21-31. 
Hadley, G. L., C. A. Wolf, and S. B. Harsh. 2006. Dairy cattle culling patterns, explanations, and implications. J. Dairy Sci. 89:22862296.

Hagemann, M., T. Hemme, A. Ndambi, O. Alqaisi, and M. N. Sultana. 2011. Benchmarking of greenhouse gas emissions of bovine milk production systems for 38 countries. Anim. Feed Sci. Technol. 166-167:46-58.

Hammond, K. J., S. Muetzel, G. C. Waghorn, C. S. Pinares-Patino, J. L. Burke, and S. O. Hoskin. 2009. The variation in methane emissions from sheep and cattle is not explained by the chemical composition of ryegrass. Proc. N.Z. Soc. Anim. Prod. 69:174-178.

Hansen, L. B. 2000. Consequences of selection for milk yield from a geneticist's viewpoint. J. Dairy Sci. 83:1145-1150.

Hansen, P. J. 2007. Exploitation of genetic and physiological determinants of embryonic resistance to elevated temperature to improve embryonic survival in dairy cattle during heat stress. Theriogenology 68S:S242-S249.

Hegarty, R. S. 1999a. Mechanisms for competitively reducing ruminal methanogenesis. Aust. J. Agric. Res. 50:1299-1306.

Hegarty, R. S. 1999b. Reducing rumen methane emissions through elimination of rumen protozoa. Aust. J. Agric. Res. 50:1321-1328.

Hegarty, R. S., and J. C. McEwan. 2010. Genetic opportunities to reduce enteric methane emissions from ruminant livestock. Abstract 515 in Book of Abstracts; Proc. 9th World Congr. Genet. Appl. Livest. Prod., Leipzig, Germany.

Herd, R. M., and P. F. Arthur. 2009. Physiological basis for residual feed intake. J. Anim. Sci. 87(E. Suppl.):E64-E71.

Hess, H. D., R. A. Beuret, M. Lötscher, I. K. Hindrichsen, A. Machmüller, J. E. Carulla, C. E. Lascano, and M. Kreuzer. 2004. Ruminal fermentation, methanogenesis and nitrogen utilization of sheep receiving tropical grass hay-concentrate diets offered with Sapindus saponaria fruits and Cratylia argentea foliage. Anim. Sci. $79: 177-189$.

Hess, H. D., T. T. Tiemann, F. Noto, J. E. Carulla, and M. Kreuzer 2006. Strategic use of tannins as means to limit methane emission from ruminant livestock. Int. Congr. Ser. 1293:164-167.

Hindrichsen, I. K., H.-R. Wettstein, A. Machmüller, B. Jörg, and M. Kreuzer. 2005. Effect of the carbohydrate composition of feed concentrates on methane emission from dairy cows and their slurry. Environ. Monit. Assess. 107:329-350.

Hironaka, R., G. W. Mathison, B. K. Kerrigan, and I. Vlach. 1996 The effect of pelleting of alfalfa hay on methane production and digestibility by steers. Sci. Total Environ. 180:221-227.

Hollmann, M., W. J. Powers, A. C. Fogiel, J. S. Liesman, N. M. Bello, and D. K. Beede. 2012. Enteric methane emissions and lactational performance of Holstein cows fed different concentrations of coconut oil. J. Dairy Sci. 95:2602-2615.

Hollmann, M., W. J. Powers, A. C. Fogiel, J. S. Liesman, N. M. Bello, and D. K. Beede. 2013. Response profiles of enteric methane emissions and lactational performance during habituation to dietary coconut oil in dairy cows. J. Dairy Sci. 96:1769-1781.

Holstein Association. 2013. Holstein breed characteristics. Accessed Oct. 28, 2013. http://www.holsteinusa.com/holstein_breed/breedhistory.html.

Holter, J. B., H. H. Hayes, W. E. Urban Jr., and A. H. Duthie. 1992. Energy balance and lactation response in Holstein cows supplemented with cottonseed with or without calcium soap. J. Dairy Sci. $75: 1480-1494$

Holtshausen, L., A. V. Chaves, K. A. Beauchemin, S. M. McGinn, T. A. McAllister, N. E. Odongo, P. R. Cheeke, and C. Benchaar. 2009. Feeding saponin-containing Yucca schidigera and Quillaja saponaria to decrease enteric methane production in dairy cows. J. Dairy Sci. 92:2809-2821.

Hristov, A. N., C. Lee, T. Cassidy, M. Long, K. Heyler, B. Corl, and R. Forster. 2011. Effects of lauric and myristic acids on ruminal fermentation, production, and milk fatty acid composition in lactating dairy cows. J. Dairy Sci. 94:382-395.

Hristov, A. N., J. Oh, C. Lee, R. Meinen, F. Montes, T. Ott, J. Firkins, A. Rotz, C. Dell, A. Adesogan, W. Yang, J. Tricarico, E. Kebreab, G. Waghorn, J. Dijkstra, and S. Oosting. 2013. Mitigation of greenhouse gas emissions in livestock production: A review of technical options for non- $\mathrm{CO}_{2}$ emissions. P. J. Gerber, B. Henderson, and H. P. S. Makkar, ed. FAO Animal Production and Health Paper No. 177. Food and Agriculture Organization of the United Nations (FAO), Rome, Italy.

Hristov, A. N., M. Vander Pol, M. Agle, S. Zaman, C. Schneider, P. Ndegwa, V. K. Vaddella, K. Johnson, K. J. Shingfield, and S. K. R. Karnati. 2009. Effect of lauric acid and coconut oil on ruminal fermentation, digestion, ammonia losses from manure, and milk fatty acid composition in lactating cows. J. Dairy Sci. 92:55615582

Hristov, A. N., G. Varga, T. Cassidy, M. Long, K. Heyler, S. K. Karnati, B. Corl, C. J. Hovde, and I. Yoon. 2010. Effect of Saccharomyces cerevisiae fermentation product on ruminal fermentation and nutrient utilization in dairy cows. J. Dairy Sci. 93:682-692.

Hubbard, K. G., D. E. Stooksbury, G. L. Hahn, and T. L. Mader 1999. A climatological perspective on feedlot cattle performance and mortality related to the temperature-humidity index. J. Prod. Agric. 12:650-653.

Huhtanen, P., M. Rinne, and J. Nousiainen. 2009. A meta-analysis of feed digestion in dairy cows. 2. The effects of feeding level and diet composition on digestibility. J. Dairy Sci. 92:5031-5042

Hungate, R. E. 1966. The Rumen and its Microbes. Academic Press, New York, NY.

Huntington, G. B., D. L. Harmon, and C. J. Richards. 2006. Sites, rates, and limits of starch digestion and glucose metabolism in growing cattle. J. Anim. Sci. 84:E14-E24.

Janssen, P. H., and M. Kirs. 2008. Structure of the archaeal community of the rumen. Appl. Environ. Microbiol. 74:3619-3625.

Jenkins, T. C. 1997. Success of fat in dairy rations depends on the amount. Feedstuffs 69:11-12.

Johnson, D. E., G. M. Ward, and J. J. Ramsey. 1996. Livestock methane: Current emissions and mitigation potential. Pages 219-233 in Nutrient Management of Food Animals to Enhance and Protect the Environment. E. T. Kornegay, ed. Lewis Publishers CRC Press Inc., Boca Raton, FL.

Johnson, D. E., G. M. Ward, and J. Torrent. 1992. The environmental impact of bovine somatotropin use in dairy cattle. J. Environ. Qual. 21:157-162.

Johnson, K. A., and D. E. Johnson. 1995. Methane emissions from cattle. J. Anim. Sci. 73:2483-2492.

Johnson, K. A., R. L. Kincaid, H. H. Westberg, C. T. Gaskins, B. K. Lamb, and J. D. Cronrath. 2002. The effect of oilseeds in diets of lactating cows on milk production and methane emissions. J. Dairy Sci. 85:1509-1515.

Jouany, J. P. 1996. Effect of rumen protozoa on nitrogen utilization by ruminants. J. Nutr. 126:1335S-1346S.

Kadzere, C. T., M. R. Murphy, N. Silanikove, and E. Maltz. 2002 Heat stress in lactating dairy cows: A review. Livest. Prod. Sci. 77:59-91.

Kebreab, E., K. Clark, C. Wagner-Riddle, and J. France. 2006. Methane and nitrous oxide emissions from Canadian animal agriculture: A review. Can. J. Anim. Sci. 86:135-158.

Kebreab, E., K. A. Johnson, S. L. Archibeque, D. Pape, and T. Wirth 2008. Model for estimating enteric methane emissions from United States dairy and feedlot cattle. J. Anim. Sci. 86:2738-2748.

Kim, M., M. Morrison, and Z. Yu. 2011. Status of the phylogenetic diversity census of ruminal microbiomes. FEMS Microbiol. Ecol. 76:49-63.

Knapp, J. R., J. L. Firkins, J. M. Aldrich, R. A. Cady, A. N. Hristov, W. P. Weiss, A. D. G. Wright, and M. D. Welch. 2011. Cow of the Future Research Priorities for Mitigating Enteric Methane Emissions from Dairy. Innovation Center for US Dairy. Accessed Apr. 1, 2014. http://www.usdairy.com/ /media/usd/public/cowofthe futurewhitepaper_7-25-11.pdf.ashx.

Kong, Y., Y. Xia, R. Seviour, R. Forster, and T. A. McAllister. 2013. Biodiversity and composition of methanogenic populations in the rumen of cows fed alfalfa hay or triticale straw. FEMS Microbiol Ecol. 84:302-315.

Kung, L., Jr., K. A. Smith, A. M. Smagala, K. M. Endres, C. A Bessett, N. K. Ranjit, and J. Yaissle. 2003. Effects of 9,10 anthra- 
quinone on ruminal fermentation, total-tract digestion, and blood metabolite concentrations in sheep. J. Anim. Sci. 81:323-328.

Laporte-Uribe, J., and S. J. Gibbs. 2009. Real time in situ measurement of rumen methane concentration in the rumen of cattle. Proc. N.Z. Soc. Anim. Prod. 69:184-187.

Lassey, K. R. 2008. Livestock methane emission and its perspective in the global methane cycle. Aust. J. Exp. Agric. 48:114-118.

LeBlanc, S. J. 2013. Is a high level of milk production compatible with good reproductive performance in dairy cows? Anim. Front. 3:84-91.

Lee, S. S., J.-T. Hsu, H. C. Mantovani, and J. B. Russell. 2002. The effect of bovicin HC5, a bacteriocin from Streptococcus bovis HC5, on ruminal methane production in vitro. FEMS Microbiol. Lett. 217:51-55

Leng, R. A. 1993. Quantitative ruminant nutrition-A green science. Aust. J. Agric. Res. 44:363-380.

Lila, Z. A., N. Mohammed, S. Kanda, M. Kurihara, and H. Itabashi. 2005. Sarsaponin effects on ruminal fermentation and microbes, methane production, digestibility and blood metabolites in steers. Asian-australas. J. Anim. Sci. 18:1746-1751.

Liu, Y., and W. B. Whitman. 2008. Metabolic, phylogenetic, and ecological diversity of the methanogenic Archaea. Ann. N. Y. Acad. Sci. 1125:171-189.

Lovett, D. K., L. Shalloo, P. Dillon, and F. P. O'Mara. 2006. A systems approach to quantify greenhouse gas fluxes from pastoral dairy production as affected by management regime. Agric. Syst. $88: 156-179$.

Lucy, M. C. 2001. Reproductive loss in high-producing dairy cattle: Where will it end? J. Dairy Sci. 84:1277-1293.

Machmüller, A., and M. Kreuzer. 1999. Methane suppression by coconut oil and associated effects on nutrient and energy balance in sheep. Can. J. Anim. Sci. 79:65-72.

Machmüller, A., M. Tavendale, J. Lee, H. Clark, and L. Meagher. 2007. Review of inhibitors of methane production. Chapter 2 in Rumen Ecology, Pastoral Greenhouse Gas Research Consortium 20022007 Review, New Zealand. Accessed June 27, 2013. http://www. pggrc.co.nz/Portals/0/annual\%20reports/PGgRc_5yearfull\%20 chapter\%202.pdf.

Martin, C., D. P. Morgavi, and M. Doreau. 2010. Methane mitigation in ruminants: From microbe to farm scale. Animal 4:351-365.

Martin, C., J. Rouel, J. P. Jouany, M. Doreau, and Y. Chilliard. 2008. Methane output and diet digestibility in response to feeding dairy cows crude linseed, extruded linseed, or linseed oil. J. Anim. Sci. 86:2642-2650.

Martin, S. A., and J. M. Macy. 1985. Effects of monensin, pyromellitic diimide and 2-bromoethanesulfonic acid on rumen fermentation in vitro. J. Anim. Sci. 60:544-550.

McAllister, T. A., and C. J. Newbold. 2008. Redirecting rumen fermentation to reduce methanogenesis. Aust. J. Exp. Agric. 48:7-13.

McCaughey, W. P., K. M. Wittenberg, and D. Corrigan. 1999. Impact of pasture type on methane production by lactating beef cows. Can. J. Anim. Sci. 79:221-226.

McCrabb, G. J., K. T. Berger, T. Magner, C. May, and R. A. Hunter. 1997. Inhibiting methane production in Brahman cattle by dietary supplementation with a novel compound and the effects on growth. Aust. J. Agric. Res. 48:323-329.

Mc Geough, E. J., S. M. Little, H. H. Janzen, T. A. McAllister, S. M. McGinn, and K. A. Beauchemin. 2012. Life-cycle assessment of greenhouse gas emissions from dairy production in Easter Canada: A case study. J. Dairy Sci. 95:5164-5175.

McGinn, S. M., K. A. Beauchemin, T. Coates, and D. Colombatto 2004. Methane emissions from beef cattle: Effects of monensin, sunflower oil, enzymes, yeast, and fumaric acid. J. Anim. Sci. 82:3346-3356.

Mills, J. A. N., E. Kebreab, C. M. Yates, L. A. Crompton, S. B. Cammell, M. S. Dhanoa, R. E. Agnew, and J. France. 2003. Alternative approaches to predicting methane emissions from dairy cows. J. Anim. Sci. 81:3141-3150.

Moate, P. J., T. Clarke, L. H. Davis, and R. H. Laby. 1997. Rumen gases and bloat in grazing dairy cattle. J. Agric. Sci. 129:459-469.
Moe, P. W., and H. F. Tyrrell. 1979. Methane production in dairy cows. J. Dairy Sci. 62:1583-1586.

Mohammed, N., N. Ajisaka, Z. A. Lila, K. Hara, K. Mikuni, K. Hara, S. Kanda, and H. Itabashi. 2004a. Effect of Japanese horseradish oil on methane production and ruminal fermentation in vitro and in steers. J. Anim. Sci. 82:1839-1846.

Mohammed, N., Z. A. Lila, N. Ajisaka, K. Hara, K. Mikuni, S. Kanda, and H. Itabashi. 2004b. Inhibition of ruminal microbial methane production by $\beta$-cyclodextrin iodopropane, malate and their combination in vitro. J. Anim. Physiol. Anim. Nutr. (Berl.) 88:188195.

Mohammed, R., S. M. McGinn, and K. A. Beauchemin. 2011. Prediction of enteric methane output from milk fatty acid concentrations and rumen fermentation parameters in dairy cows fed sunflower, flax, or canola seeds. J. Dairy Sci. 94:6057-6068.

Molano, G., T. W. Knight, and H. Clark. 2008. Fumaric acid supplements have no effect on methane emissions per unit of feed intake in wether lambs. Aust. J. Exp. Agric. 48:165-168.

Morgavi, D. P., E. Forano, C. Martin, and C. J. Newbold. 2010. Microbial ecosystem and methanogenesis in ruminants. Animal 4:1024-1036.

Morgavi, D. P., C. Martin, J. P. Jouany, and M. J. Ranilla. 2012. Rumen protozoa and methanogenesis: Not a simple cause-effect relationship. Br. J. Nutr. 107:388-397.

Mosoni, P., C. Martin, E. Forano, and D. P. Morgavi. 2011. Long-term defaunation increases the abundance of cellulolytic ruminococci and methanogens but does not affect the bacterial and methanogen diversity in the rumen of sheep. J. Anim. Sci. 89:783-791.

Moss, A. R., D. I. Givens, and P. C. Garnsworthy. 1994. The effect of alkali treatment of cereal straws on digestibility and methane production by sheep. Anim. Feed Sci. Technol. 49:245-259.

Moss, A. R., J. P. Jouany, and J. Newbold. 2000. Methane production by ruminants: Its contribution to global warming. Ann. Zootech. 49:231-253.

Münger, A., and M. Kreuzer. 2006. Methane emission as determined in contrasting dairy cattle breeds over the reproduction cycle. Int. Congr. Ser. 1293:119-122.

Muñoz, C., T. Yan, D. A. Wills, S. Murray, and A. W. Gordon. 2012. Comparison of the sulfur hexafluoride tracer and respiration chamber techniques for estimating methane emissions and correction for rectum methane output from dairy cows. J. Dairy Sci. 95:31393148 .

Murphy, M. R., R. L. Baldwin, and L. J. Koong. 1982. Estimation of stoichiometric parameters for rumen fermentation of roughage and concentrate diets. J. Anim. Sci. 55:411-421.

Mutsvangwa, T., I. E. Edwards, J. H. Topps, and G. F. M. Paterson. 1992. The effect of dietary inclusion of yeast culture (Yea-Sacc) on patterns of rumen fermentation, food intake and growth of intensively fed bulls. Anim. Prod. 55:35-40.

NRC. 2001. Nutritional Requirements of Dairy Cattle. 7th ed. National Academy Press, Washington, DC.

O'Neill, B. F., M. H. Deighton, B. M. O'Loughlin, N. Galvin, M O'Donovan, and E. Lewis. 2012. The effects of supplementing grazing dairy cows with partial mixed ration on enteric methane emissions and milk production during mid to late lactation. J. Dairy Sci. 95:6582-6590.

Odongo, N. E., R. Bagg, G. Vessie, P. Dick, M. M. Or-Rashid, S. E. Hook, J. T. Gray, E. Kebreab, J. France, and B. W. McBride. 2007a. Long-term effects of feeding monensin on methane production in lactating dairy cows. J. Dairy Sci. 90:1781-1788.

Odongo, N. E., M. M. Or-Rashid, E. Kebreab, J. France, and B. W. Bride. 2007b. Effect of supplementing myristic acid in dairy cow rations on ruminal methanogenesis and fatty acid profile in milk. J. Dairy Sci. 90:1851-1858.

Okine, E. K., G. W. Mathison, and R. T. Hardin. 1989. Effects of changes in frequency of reticular contractions on fluid and particulate passage rates in cattle. J. Anim. Sci. 67:3388-3396.

Olson, K. M., B. G. Cassell, and M. D. Hanigan. 2010. Energy balance in first-lactation Holstein, Jersey, and reciprocal $\mathrm{F}_{1}$ crossbred cows in a planned crossbreeding experiment. J. Dairy Sci. 93:4374-4385. 
Ominski, K. H., and K. M. Wittenberg. 2005. Strategies for reducing enteric methane emissions in forage-based beef production systems. Pages 261-272 in Climate Change and Managed Ecosystems. J. S. Bhatti, R. Lal, M. J. Apps, and M. A. Price, ed. CRC Press, Boca Raton, FL.

Overton, M., and J. Fetrow. 2008. Economics of postpartum uterine health. Pages 24-29 in Proc. 2008 Dairy Cattle Reproduction Council Convention, Omaha, NE. Dairy Cattle Reproduction Council, Champaign, IL.

Pen, B., K. Takaura, S. Yamaguchi, R. Asa, and J. Takahashi. 2007. Effects of Yucca schidigera and Quillaja saponaria with or without $\beta$ 1-4 galacto-oligosaccharides on ruminal fermentation, methane production and nitrogen utilization in sheep. Anim. Feed Sci. Technol. 138:75-88.

Petherick, A. 2012. Light is cast on a long shadow. Nature Climate Change 2:705-706.

Phetteplace, H. W., D. E. Johnson, and A. F. Seidl. 2001. Greenhouse gas emissions from simulated beef and dairy livestock systems in the United States. Nutr. Cycl. Agroecosyst. 60:99-102.

Pinares-Patiño, C. S., S. M. Hickey, E. A. Young, K. G. Dodds, S. MacLean, G. Molano, E. Sandoval, H. Kjestrup, R. Harland, C. Hunt, N. K. Pickering, and J. C. McEwan. 2013. Heritability estimates of methane emissions from sheep. Animal 7(Suppl. 2):316-321.

Pinares-Patiño, C. S., G. C. Waghorn, R. S. Hegarty, and S. O. Hoskin. 2009. Effects of intensification of pastoral farming on greenhouse gas emissions in New Zealand. N. Z. Vet. J. 57:252-261.

Pinares-Patiño, C. S., G. C. Waghorn, A. Machmüller, B. Vlaming, G. Molano, A. Cavanagh, and H. Clark. 2007. Methane emissions and digestive physiology of non-lactating dairy cows fed pasture forage. Can. J. Anim. Sci. 87:601-613.

Pitesky, M. E., K. R. Stackhouse, and F. M. Mitloehner. 2009. Clearing the air: Livestock's contribution to climate change. Adv. Agron. 103:1-40.

Poulsen, M., C. Schwab, B. B. Jensen, R. M. Engberg, A. Spang, N. Canibe, O. Højberg, G. Milinovich, L. Fragner, C. Schleper, W. Weckwerth, P. Lund, A. Schramm, and T. Urich. 2013. Methylotrophic methanogenic Thermoplasmata implicated in reduced methane emissions from bovine rumen. Nature Comm. 4:1428. http://dx.doi.org/10.1038/ncomms2432.

Ravagnolo, O., and I. Misztal. 2000. Genetic component of heat stress in dairy cattle, parameter estimation. J. Dairy Sci. 83:2126-2130.

Rauw, W. M., E. Kanis, E. N. Noordhuizen-Stassen, and F. J. Grommers. 1998. Undesirable side effects of selection for high production efficiency in farm animals: A review. Livest. Prod. Sci. 56:15-33.

Rhoads, M. L., R. P. Rhoads, M. J. VanBaale, R. J. Collier, S. R. Sanders, W. J. Weber, B. A. Crooker, and L. H. Baumgard. 2009. Effects of heat stress and plane of nutrition on lactating Holstein cows: I. Production, metabolism, and aspects of circulating somatotropin. J. Dairy Sci. 92:1986-1997.

Rius, A. G., S. Kittelmann, K. A. Macdonald, G. C. Waghorn, P. H. Janssen, and E. Sikkema. 2012. Nitrogen metabolism and rumen microbial enumeration in lactating cows with divergent residual feed intake fed high-digestibility pasture. J. Dairy Sci. 95:50245034

Robertson, L. J., and G. C. Waghorn. 2002. Dairy industry perspectives on methane emissions and production from cattle fed pasture or total mixed rations in New Zealand. Proc. N.Z. Soc. Anim. Prod. 62:213-218.

Ross, E. M., P. J. Moate, L. Marett, B. G. Cocks, and B. J. Hayes. 2013. Investigating the effect of two methane-mitigating diets on the rumen microbiome using massively parallel sequencing. J. Dairy Sci. 96:6030-6046.

Russell, J. B., and R. B. Hespell. 1981. Microbial rumen fermentation. J. Dairy Sci. 64:1153-1169.

Santoso, B., B. Mwenya, C. Sar, Y. Gamo, T. Kobayashi, R. Morikawa, K. Kimura, H. Mizukoshi, and J. Takahashi. 2004. Effects of supplementing galactooligosaccharides, Yucca schidigera or nisin on rumen methanogenesis, nitrogen and energy metabolism in sheep. Livest. Prod. Sci. 91:209-217.

Sar, C., B. Santoso, B. Mwenya, Y. Gamo, T. Kobayashi, R. Morikawa, K. Kimura, H. Mizukoshi, and J. Takahashi. 2004. Manipu- lation of rumen methanogenesis by the combination of nitrate with 31-4 galacto-oligosaccharides or nisin in sheep. Anim. Feed Sci. Technol. 115:129-142.

Sauvant, D., and S. Giger-Reverdin. 2009. Modélisation des ineractions digestives et de la production de méthane chez les ruminants. INRA Prod. Anim. 22:375-384.

Schrick, F. N., M. E. Hockett, A. M. Saxton, M. J. Lewis, H. H Dowlen, and S. P. Oliver. 2001. Influence of subclinical mastitis during early lactation on reproductive parameters. J. Dairy Sci. 84:1407-1412.

Schroeder, G. G., G. A. Gagliostro, F. Bargo, J. E. Delahoy, and L. D. Muller. 2004. Effects of fat supplementation on milk production and composition by dairy cows on pasture: A review. Livest. Prod. Sci. 86:1-18.

Shafer, S. R., C. L. Walthall, A. J. Franzluebbers, M. Scholten, J. Meijs, H. Clark, A. Reisinger, K. Yagi, A. Roel, B. Slattery, I. D. Campbell, B. G. McConkey, D. A. Angers, J. F. Soussana, and G. Richard. 2011. Emergence of the global research alliance on agricultural greenhouse gases. Carbon Management 2:209-214.

Shook, G. E. 2006. Major advances in determining appropriate selection goals. J. Dairy Sci. 89:1349-1361.

St-Pierre, N. R. 1998. A model for projecting animal numbers in a closed herd. Department of Animal Sciences Research and Reviews, OARDC Special Circular \#163, 37-43. Accessed Mar. 11 2011. http://ohioline.osu.edu/sc163/sc163_6.html.

St-Pierre, N. R., B. Cobanov, and G. Schnitkey. 2004. Economic losses from heat stress by US livestock industries. J. Dairy Sci. 86(E. Suppl.):E52-E77.

St-Pierre, N. R., and C. S. Thraen. 1999. Animal grouping strategies, sources of variation, and economic factors affecting nutrient balance on dairy farms. J. Anim. Sci. 77(Suppl. 2):72-83.

Staerfl, S. M., S. L. Amelchanka, T. Kälber, C. R. Soliva, M. Kreuzer, and J. O. Zeitz. 2012. Effect of feeding dried high-sugar ryegrass ('AberMagic') on methane and urinary nitrogen emissions of primiparous cows. Livest. Sci. 150:293-301.

Steinfeld, H., P. Gerber, T. Wassenaar, V. Castel, M. Rosales, and C. de Haan. 2006. Livestock's Long Shadow. Food and Agriculture Organization of the United Nations. Accessed Mar. 8, 2012. http://www.fao.org/docrep/010/a0701e/a0701e00.htm.

Storm, I. M. L. D., A. L. F. Hellwing, N. I. Nielsen, and J. Madsen. 2012. Methods for measuring and estimating methane emissions from ruminants. Animals 2:160-183.

Sundstol, F. 1981. Methods for treatment of low quality roughages. Pages $61-80$ in Utilization of low quality roughages in Africa. A workshop held at Arusha, Tanzania. J. A. Kategile, A. N. Said, and F. Sundstol, ed. Lamport Gilbert Printers Ltd., Reading, UK.

Sutton, J. D., M. S. Dhanoa, S. V. Morant, J. France, D. J. Napper, and E. Schuller. 2003. Rates of production of acetate, propionate and butyrate in the rumen of lactating dairy cows given normal and low-roughage diets. J. Dairy Sci. 86:3620-3633.

Takahashi, J., A. S. Chaudhry, R. G. Beneke, Suhubdy, and B. A. Young. 1997. Modification of methane emission in sheep by cysteine and a microbial preparation. Sci. Total Environ. 204:117-123.

Thoma, G., J. Popp, D. Nutter, D. Shonnard, R. Ulrich, M. Matlock, D. S. Kim, Z. Neiderman, N. Kemper, C. East, and F. Adom. 2013. Greenhouse gas emissions from milk production and consumption in the United States: A cradle-to-grave life cycle assessment circa 2008. Int. Dairy J. 31(Suppl.1):S3-S14.

Tyrell, H. F., and P. W. Moe. 1975. Effect of intake on digestive efficiency. J. Dairy Sci. 58:1151-1163.

Tyrrell, H. F., C. K. Reynolds, and H. D. Blaxter. 1991. Utilization of dietary energy by Jersey compared to Holstein cows during the lactation cycle. Proc. 12th Symp. Energy Metabolism of Farm Animals. EAAP Publ. 58. European Federation for Animal Science (EAAP), Rome, Italy.

Uribe, H. A., B. W. Kennedy, S. W. Martin, and D. F. Kelton. 1995 Genetic parameters for common health disorders of Holstein cows. J. Dairy Sci. 78:421-430.

USDA. 2012. Animal Improvement Programs Laboratory Bovine Genetics Trend data. Accessed Mar. 19, 2014. https://www.cdcb.us eval/summary/trend.cfm?R_Menu=HO. 
Utsumi, S., D. Beede, S. Zimmerman, and P. Zimmerman. 2011. Whole herd enteric methane emission estimates in three contrasting dairy systems. J. Dairy Sci. 94(E-Suppl. 1):607.

Vandehaar, M. J. 1998. Efficiency of nutrient use and relationship to profitability on dairy farms. J. Dairy Sci. 81:272-282.

van Dorland, H. A., H.-R. Wettstein, H. Leuenberger, and M. Kreuzer. 2007. Effect of supplementation of fresh and ensiled clovers to ryegrass on nitrogen loss and methane emission of dairy cows. Livest. Sci. 111:57-69.

van Kessel, J. A. S., and J. B. Russell. 1996. The effect of $\mathrm{pH}$ on ruminal methanogenesis. FEMS Microbiol. Ecol. 20:205-210.

Van Nevel, C. J., and D. I. Demeyer. 1996. Control of rumen methanogenesis. Environ. Monit. Assess. 42:73-97.

VanRaden, P. M. 2004. Invited review: Selection on net merit to improve lifetime profit. J. Dairy Sci. 87:3125-3131.

van Zijderveld, S. M., W. J. J. Gerrits, J. A. Apajalahti, J. R. Newbold, J. Dijkstra, R. A. Leng, and H. B. Perdok. 2010. Nitrate and sulfate: Effective alternative hydrogen sinks for mitigation of ruminal methane production in sheep. J. Dairy Sci. 93:5856-5866.

van Zijderveld, S. M., W. J. J. Gerrits, J. Dijkstra, J. R. Newbold, R. B. A. Hulshof, and H. B. Perdok. 2011. Persistency of methane mitigation by dietary nitrate supplementation in dairy cows. J. Dairy Sci. 94:4028-4038.

Vlaming, J. B., N. Lopez-Villalobos, I. M. Brookes, S. O. Hoskin, and H. Clark. 2008. Within- and between-animal variance in methane emissions in non-lactating dairy cows. Aust. J. Exp. Agric. 48:124-127.

Waghorn, G. 2008. Beneficial and detrimental effects of dietary condensed tannins for sustainable sheep and goat production-Progress and challenges. Anim. Feed Sci. Technol. 147:116-139.

Waghorn, G. C. 2011. Can livestock production be increased without increasing greenhouse gas emissions? Proc. N.Z. Soc. Anim. Prod. 71:156-162.

Waghorn, G. C., and D. A. Clark. 2006. Greenhouse gas mitigation opportunities with immediate application to pastoral grazing for ruminants. Int. Congr. Ser. 1293:107-110.

Waghorn, G. C., H. Clark, V. Taufa, and A. Cavanagh. 2008. Monensin controlled-release capsules for methane mitigation in pasturefed dairy cows. Aust. J. Exp. Agric. 48:65-68.

Waghorn, G. C., and R. S. Hegarty. 2011. Lowering ruminant methane emissions through improved feed conversion efficiency. Anim. Feed Sci. Technol. 166-167:291-301.

Wall, E., M. P. Coffey, and G. E. Pollott. 2012. The effect of lactation length on greenhouse gas emissions from the national dairy herd. Animal 6:1857-1867.

Wallace, R. J., T. A. Wood, A. Rowe, J. Price, D. R. Yanez, S. P. Williams, and C. J. Newbold. 2006. Encapsulated fumaric acid as a means of decreasing ruminal methane emissions. Int. Congr. Ser. 1293:148-151.

Wang, C. J., S. P. Wang, and H. Zhou. 2009. Influences of flavomycin, ropadiar, and saponin on nutrient digestibility, rumen fermentation, and methane emission from sheep. Anim. Feed Sci. Technol. 148:157-166.

Weimer, P. J. 1998. Manipulating ruminal fermentation: A microbial ecological perspective. J. Anim. Sci. 76:3114-3122.

Williams, Y. J., S. Popovski, S. M. Rea, L. C. Skillman, A. F. Toovey, K. S. Northwood, and A. D. Wright. 2009. A vaccine against rumen methanogens can alter the composition of archaeal populations. Appl. Environ. Microbiol. 75:1860-1866.

Williams, Y. J., S. M. Rea, S. Popovski, C. L. Pimm, A. J. Williams, A. F. Toovey, L. C. Skillman, and A.-D. G. Wright. 2008. Reponses of sheep to a vaccination of entodinial or mixed rumen protozoal antigens to reduce rumen protozoal numbers. Br. J. Nutr. 99:100-109.

Wolin, M. J. 1974. Metabolic interactions among intestinal microorganisms. Am. J. Clin. Nutr. 27:1320-1328.

Woodward, S. L., G. C. Waghorn, K. R. Lassey, and P. G. Laboyrie. 2002. Does feeding sulla (Hedysarum coronarium) reduce methane emissions from dairy cows? Proc. N.Z. Soc. Anim. Prod. 62:227230

Wright, A. D. G., P. Kennedy, C. J. O'Neill, A. F. Toovey, S. Popovski, S. M. Rea, C. L. Pimm, and L. Klein. 2004. Reducing methane emissions in sheep by immunization against rumen methanogens. Vaccine 22:3976-3985.

Wright, A.-D. G., A. F. Toovey, and C. L. Pimm. 2006. Molecular identification of methanogenic Archaea from sheep in Queensland, Australia reveal more uncultured novel Archaea. Anaerobe 12:134-139.

Yang, W. Z., K. A. Beauchemin, and L. M. Rode. 2001. Effects of grain processing, forage to concentrate ratio, and forage particle size on rumen $\mathrm{pH}$ and digestion by dairy cows. J. Dairy Sci. 84:2203-2216.

Zehetmeier, M., J. Baudracco, H. Hoffmann, and A. Heißenhuber. 2012. Does increasing milk yield per cow reduce greenhouse gas emissions? A system approach. Animal 6:154-166.

Zimbelman, R. B. 2008. Management strategies to reduce effects of thermal stress on lactating dairy cattle. PhD Diss. University of Arizona, Tucson

Zwald, N. R., K. A. Weigel, Y. M. Chang, R. D. Welper, and J. S. Clay. 2004. Genetic selection for health traits using producerrecorded data. I. Incidence rates, heritability estimates, and sire breeding values. J. Dairy Sci. 87:4287-4294. 